\title{
Food security and the functioning of wheat markets in Eurasia: a comparative price transmission analysis for the countries of Central Asia and the South Caucasus
}

\author{
Miranda Svanidze ${ }^{1}$ [D $\cdot$ Linde Götz $^{1} \cdot$ Ivan Djuric $^{1} \cdot$ Thomas Glauben $^{1}$ \\ Received: 28 March 2018 / Accepted: 1 May 2019 / Published online: 31 May 2019 \\ (C) The Author(s) 2019
}

\begin{abstract}
We investigated wheat price relationships between the import-dependent countries in Central Asia and the South Caucasus and the Black Sea wheat exporters to assess wheat market efficiency. This is crucial for ensuring availability and access to wheat and for reducing food insecurity. Results from linear and threshold error correction models suggested a strong influence of trade costs on market integration in Central Asia, while those costs were of minor importance in the South Caucasus. In particular, wheat trade in Central Asia is characterized by higher transportation costs but unofficial payments also play a large role. In addition, wheat price volatility is substantially higher in the wheat importing countries of Central Asia compared to the South Caucasus. To foster market functioning, wheat trade should be facilitated by policies that reduce the costs of trade. These include investments in grain market infrastructure, eliminating unofficial payments, and resolving geopolitical conflicts. Additionally, large distances characterize wheat trade in this region, low scope for import diversification and repeated export restrictions by Black Sea exporters. Therefore, trade-enhancing policies should be complemented with policies that increase wheat self-sufficiency in order to improve food security.
\end{abstract}

Keywords Price transmission · Wheat market integration · Transportation costs · Food security $\cdot$ Central Asia $\cdot$ The South Caucasus

\section{Introduction}

The efficiency of agricultural and food markets strongly influences food security by determining the availability of food products and the level of end consumer food prices (FAO 2009). Food prices affect nutritional status, especially of poor

Miranda Svanidze

svanidze@iamo.de

Linde Götz

goetz@iamo.de

Ivan Djuric

djuric@iamo.de

Thomas Glauben

glauben@iamo.de

1 Leibniz Institute of Agricultural Development in Transition Economies (IAMO), Theodor-Lieser-Str. 2, 06120 Halle (Saale), Germany households, which spend large shares of their income on food (Matz et al. 2015).

Food insecurity is prevalent in countries of Central Asia and the South Caucasus ${ }^{1}$ (Schroeder and Meyers 2016). Populations in these countries derive on average between $40 \%$ and $60 \%$ of their total dietary energy supply solely from wheat, which is heavily imported from the wheat exporting countries of the Black Sea region. Specifically, Russia, Kazakhstan, and Ukraine account for over $90 \%$ of total wheat imports to Central Asian and South Caucasian countries (UN Comtrade 2016). The Black Sea region accounts for the largest share of global wheat exports; however, exports from this region are highly unstable due to harvest shortfalls and export restrictions (Fellmann et al. 2014). Since wheat is the primary source of calories in Central Asia and the South Caucasus, the efficient functioning of grain markets in those regions is essential for alleviating food insecurity. In the future, harvest shortfalls due

\footnotetext{
${ }^{1}$ Throughout this study, the term "Central Asia" refers to the countries Kyrgyzstan, Tajikistan, and Uzbekistan. The South Caucasus includes Armenia, Azerbaijan, and Georgia.
} 
to climate-change-related weather extremes are expected to increase in Central Asia (Ubilava 2017), further increasing the necessity of well-functioning grain markets in this region.

This paper investigates the functioning of domestic wheat markets in wheat import-dependent countries of Central Asia and the South Caucasus by studying the integration of these markets with the wheat export markets in the Black Sea region and with global wheat markets.

Well-functioning domestic wheat markets that are strongly integrated in regional or world wheat markets promote the efficient allocation of resources. An integrated market is characterized by co-moving prices that are in equilibrium with the prices in spatially separated markets. In a spatially efficient market, the Law of One Price holds, i.e., the price difference observed between spatially separated markets equals the respective trade costs at most (Takayama and Judge 1971). ${ }^{2}$ From a dynamic perspective, prices may temporarily deviate from the price equilibrium due to market shocks, but trade arbitrage, with which traders exploit price differences exceeding trade costs, will quickly correct such deviations (Fackler and Goodwin 2001). In that sense, a high level of trade fosters market integration and contributes to the stabilization of prices. Based on the results of a panel analysis of 151 countries, Dithmer and Abdulai (2017) found that trade openness positively impacts food security. Studies on market integration also provide evidence for market competitiveness. If we find that two markets are strongly integrated, we can also infer that they are competitive, since price differences are quickly arbitraged in strongly integrated markets (Dillon and Dambro 2017).

As an example, in a strongly integrated market, a regional grain harvest shortfall triggers price increases, which are quickly transmitted to other markets, thereby inducing concomitant trade flows that eventually act to stem rising prices (Goodwin and Piggott 2001). By contrast, a region that is only weakly integrated in regional and world wheat markets might be restricted from accessing export markets, and then only at high costs (Jamora and von Cramon-Taubadel 2016). In this case, rising regional prices will induce only limited trade inflows, thereby negatively affecting the availability and access to a sufficient, reasonably priced grain supply.

In this paper we analyzed how prices observed within the Central Asian wheat markets of Kyrgyzstan, Tajikistan, and Uzbekistan and the South Caucasian wheat markets of Azerbaijan, Armenia, and Georgia relate to prices of the Black Sea wheat export markets (Russia, Ukraine, and Kazakhstan) and the world markets (France and the USA). We complement this price transmission analysis with the analysis of historical wheat price volatility in these markets.

\footnotetext{
"We use the terms "trade costs" and "transaction costs" interchangeably. Transportation costs (sometimes referred to as shipping costs) are only part of trade costs.
}

Wheat markets in Central Asia and the South Caucasus have only been studied in a rudimentary fashion in the existing literature and their degree of efficiency is under-researched. This can, at least in part, be explained by the limited availability of, and accessibility to, suitable data (Brück et al. 2012). Unlike the case of the Black Sea wheat exporting countries, where strong interest in their respective markets from international agricultural trading companies has spurred private data collection efforts, these kinds of data are often not publicly available for the wheat import-dependent countries of Central Asia and the South Caucasus.

Existing studies on wheat markets in the South Caucasus region have found that domestic wheat markets are well integrated into the world market system and are characterized by a symmetrical adjustment of price deviations from equilibrium (Bluashvili and Safaryan 2014; Djuric et al. 2017; Katsia and Mamardashvili 2016). In contrast, grain price relationships across the Central Asian countries indicate more heterogeneous patterns of price transmission, ranging from wellintegrated to completely segregated wheat markets (Bobokhonov et al. 2017; Chabot and Dorosh 2007; Ilyasov 2016; Ilyasov et al. 2016).

Differing from existing studies, we follow a comparative approach and investigate market integration in the six selected countries of Central Asia and the South Caucasus within a unified price transmission modelling approach. A comparative approach may permit a more comprehensive interpretation of the estimated parameters. In price transmission analysis, the estimated parameters themselves enable judgment of how well a market is functioning to a limited degree only. We tackle this issue by investigating markets with differing characteristics within a similar modelling approach, allowing the estimated model parameters to be directly compared.

By using the non-linear, threshold-type price transmission model approach (Greb et al. 2013), we explicitly accounted for trade costs that strongly influence market integration (Fiamohe et al. 2013; Jamora and von Cramon-Taubadel 2016; Moser et al. 2009; Svanidze and Götz 2019; van Campenhout 2007). Poor transportation infrastructure and high shipping costs, as well as excessive bureaucratic requirements, are problematic throughout Central Asia (ADB 2006; Pomfret 2016; World Bank 2011). This is less of a concern for the South Caucasian countries, as the export markets in the Black Sea region can be accessed through Georgia's ports.

The paper is organized as follows: Section 2 provides a general overview of food security and domestic wheat markets in Central Asia and the South Caucasus, while section 3 introduces the model framework and research question. In section 4, we discuss the data and in section 5 we share our empirical results. Policy recommendations and a discussion are provided in section 6 , followed by our conclusions in section 7. 


\section{Food security, the wheat trade, and transportation costs in Central Asia and the South Caucasus}

Food insecurity is chronic in most of the Central Asian countries and critical in the South Caucasus region (Akramov 2012; Bobojonov et al. 2017; Chabot and Tondel 2011; Swinnen and van Herck 2011). Stunting in children less than five years of age averages $22 \%$ in Central Asia and $17 \%$ in the South Caucasus. In addition, $7 \%$ of child populations in Central Asia and 4\% in the South Caucasus are underweight (see Table 1 for individual shares). The UN's World Food Programme, a humanitarian organization fighting hunger worldwide, also operates in the Central Asian countries of Kyrgyzstan and Tajikistan, as well as in Armenia in the South Caucasus.

In addition, households in these regions spend a large portion of their income on food, as much as $49 \%$ on average in Armenia and $63 \%$ in Tajikistan, for example (Table 1). Among all food items, wheat, mainly in the form of bread, accounts for a large share of total daily food calories, ranging from $40 \%$ to $60 \%$ in both regions. Since household welfare largely depends on the level of food prices, increased food prices often lead to social and political unrest. During recent food price hikes, organized public protests were observed in Uzbekistan in September 2007 (Ortiz et al. 2013); in Tajikistan in February 2008 (RFE/RL 2008); and in Kyrgyzstan in April 2010 (Swinnen and Van Herck 2013). Furthermore, Veninga and Ihle (2018) found that violent political conflicts in Egypt caused wheat import disruptions in the world's largest wheat importing country in 2011.

Most governments in Central Asia have emphasized wheat self-sufficiency as an important goal that they aspire to within their national food security policy (FAO 2015a, b). In Uzbekistan, for example, wheat production is still centrally planned. The government, through its land leasing contracts, sets quotas for the land area under wheat cultivation and defines yield and production targets to be met by farmers.
Although input subsidies are provided, the government also obliges farmers to sell $50 \%$ of their produce to state enterprises at the predetermined fixed price. State procurement prices are about three to five times lower than counterfactual market prices (Pugach et al. 2016). For the case of Kyrgyzstan and Tajikistan, even though their National Food Security Programs aim to achieve wheat self-sufficiency, these countries apply more liberal agricultural policy measures and remain heavily dependent on wheat imports.

Among the South Caucasian countries, the level of government support is lowest (practically non-existent) in Georgia and Armenia, and relatively high in Azerbaijan. In particular, farmers in Azerbaijan receive subsidies for fertilizers, fuel, machinery, and seed production, as well as monetary transfers (Robinson 2008); however, contrary to Uzbekistan, the government of Azerbaijan does not oblige farmers to sell their grain to state procurement agencies. Investments from Kazakhstan also play an important role in the development of the wheat trade and processing sector in Azerbaijan (FAO/EBRD 2009).

Nonetheless, in the countries of Central Asia and the South Caucasus, domestic wheat production falls very short of meeting local wheat demand. On average, imports account for $41 \%$ of wheat consumption in Central Asia and 63\% in the South Caucasus (Table 1). With the increasing impact of climate change and the growing water shortages associated with it, wheat yields are forecasted to decline over time. Also, variability in wheat production, and ultimately wheat imports, is expected to increase in Central Asia (Sutton et al. 2013).

Central Asian countries import their wheat almost exclusively from Kazakhstan, whereas wheat to the South Caucasian countries is mainly imported from Russia, Kazakhstan, and, to a lesser extent, from Ukraine (Fig. 1). In the recent past, the Black Sea region's wheat exporting countries experienced severe harvest shortfalls and implemented various export control systems during periods of high and volatile prices (Götz et al. 2016). During wheat export restrictions, wheat imports to countries in Central Asia and the South

Table 1 Country-specific economic indicators in countries of Central Asia and the South Caucasus

\begin{tabular}{|c|c|c|c|c|c|c|}
\hline \multirow[b]{2}{*}{$\begin{array}{l}\text { Country } \\
\text { Economic indicator }\end{array}$} & \multicolumn{3}{|l|}{ Central Asia } & \multicolumn{3}{|c|}{ South Caucasus } \\
\hline & Kyrgyzstan & Tajikistan & Uzbekistan & Armenia & Azerbaijan & Georgia \\
\hline $\begin{array}{l}\text { Share of household expenditure on food and non-alcoholic } \\
\text { beverages }(\%), 2012\end{array}$ & 46 & 63 & 31 & 49 & 43 & 35 \\
\hline $\begin{array}{l}\text { Share of wheat as \% of total food calorie supply (kcal/capita/day), } \\
\text { average of 2004-2011 }\end{array}$ & 38 & 52 & 52 & 40 & 56 & 40 \\
\hline $\begin{array}{l}\text { Share of imports in total wheat domestic consumption (\%), } \\
\text { average of 2006-2014 }\end{array}$ & 36 & 66 & 22 & 58 & 44 & 93 \\
\hline Prevalence of stunting in children under $5(\%)$ & $18(2012)$ & $27(2012)$ & $20(2006)$ & $21(2010)$ & $18(2013)$ & $11(2009)$ \\
\hline Prevalence of underweight in children under $5(\%)$ & $4(2012)$ & $13(2012)$ & $4(2006)$ & $5(2010)$ & $5(2013)$ & 1 (2009) \\
\hline
\end{tabular}

FAO (2015a, b), USDA-ERS (2016), USDA-FAS (2016), WFP (2016), WHO (2016) 
Kyrgyzstan

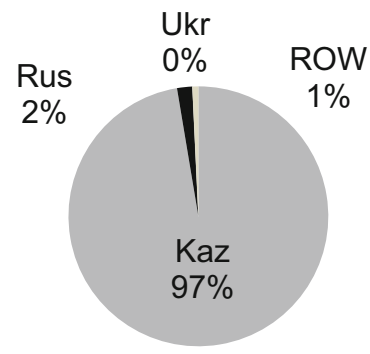

Armenia

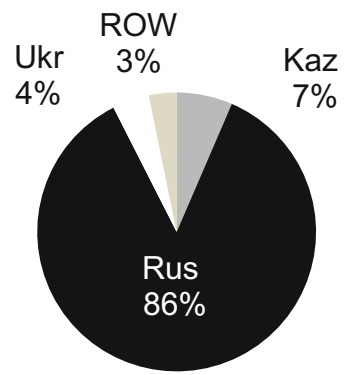

Tajikistan

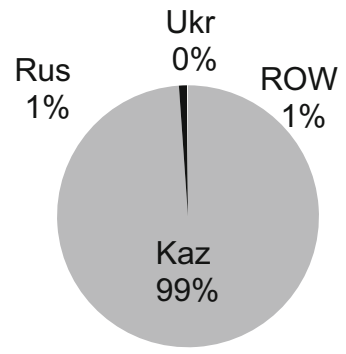

Azerbaijan

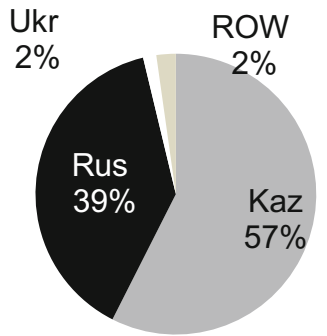

Uzbekistan

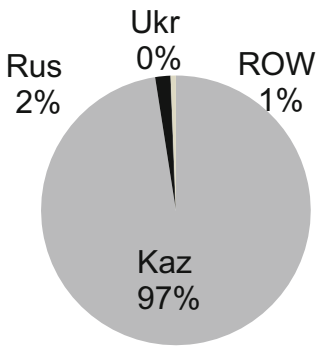

Georgia

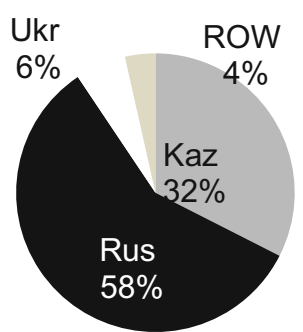

Fig. 1 Share of the Black Sea region in total wheat imports to Central Asia and the South Caucasus, 2006-2014. Source: UN Comtrade (2016). Note: ROW="Rest of the World", i.e., countries other than Russia, Ukraine, and Kazakhstan are included

Caucasus from Russia, Ukraine, and Kazakhstan were substituted by imports from more distant countries, such as Iran and European countries.

Countries of Central Asia and the South Caucasus differ substantially in terms of the structure and size of their transportation costs. The Central Asian countries are landlocked and can access the Black Sea exporting markets only through Kazakhstan (Fig. 2). In Central Asian countries, wheat is shipped mainly by rail and secondarily by truck. Northern Kyrgyzstan and Uzbekistan can import wheat directly from Kazakhstan, whereas most rail shipments to southern Kyrgyzstan and Tajikistan must first pass through Uzbekistan.

In contrast, the South Caucasian country of Georgia utilizes its Black Sea ports, through which wheat can be imported directly from Russia and Ukraine (Fig. 2). Armenia depends on Georgia's rail network for transporting imported wheat from Georgia's Black Sea ports to its border. Georgia may also import wheat from Kazakhstan by freight train, which passes through Russia and Azerbaijan. Azerbaijan relies on rail shipments of wheat directly from Russia and utilizes the Russian rail system as well to access Ukrainian and Kazakh wheat. Due to the military conflict between Armenia and Azerbaijan, the border between the two countries is closed, forcing Armenia to import Kazakh wheat through Georgia, significantly increasing the price of Kazakh wheat and making it less competitive for Armenia compared to purchasing wheat from other Black Sea export markets.
Countries in the South Caucasus import wheat from Russia and Ukraine nearly twice as cheaply as that from Kazakhstan (Table 2). Higher freight rates for wheat imports from Kazakhstan result from large distances and inefficient and outdated logistics systems in Kazakhstan inherited from Soviet Union times.

Shipping costs (official rates) of wheat from Kazakhstan to the Central Asian countries of Kyrgyzstan and Tajikistan are comparable to shipping costs to the South Caucasian countries of Azerbaijan and Georgia (Table 2). However, due to unofficial payments, the total cost of transportation could be double the official payments in Central Asia (ADB 2006; Chabot and Tondel 2011; World Bank 2005).

Unofficial payments are paid at custom checkpoints and to the traffic police. For example, a test conducted by the Asian Development Bank (ADB 2006) showed that unofficial payments paid by truck drivers on the route between Kyrgyzstan and Kazakhstan were three to four times higher than the official transportation costs. Another experiment by the World Bank (2011) demonstrated that unofficial payments for in-country transportation of cargos from the northern to the southern part of Kyrgyzstan may account for $9 \%$ of total transportation costs. Payments were extracted by transport control authorities and traffic police. Pomfret (2016) points out that trade in Central Asia is not only characterized by high transportation costs, but also by inadequate regional trade infrastructure, resulting in slow movement of cargos and long delays at the border crossing points in this region. 


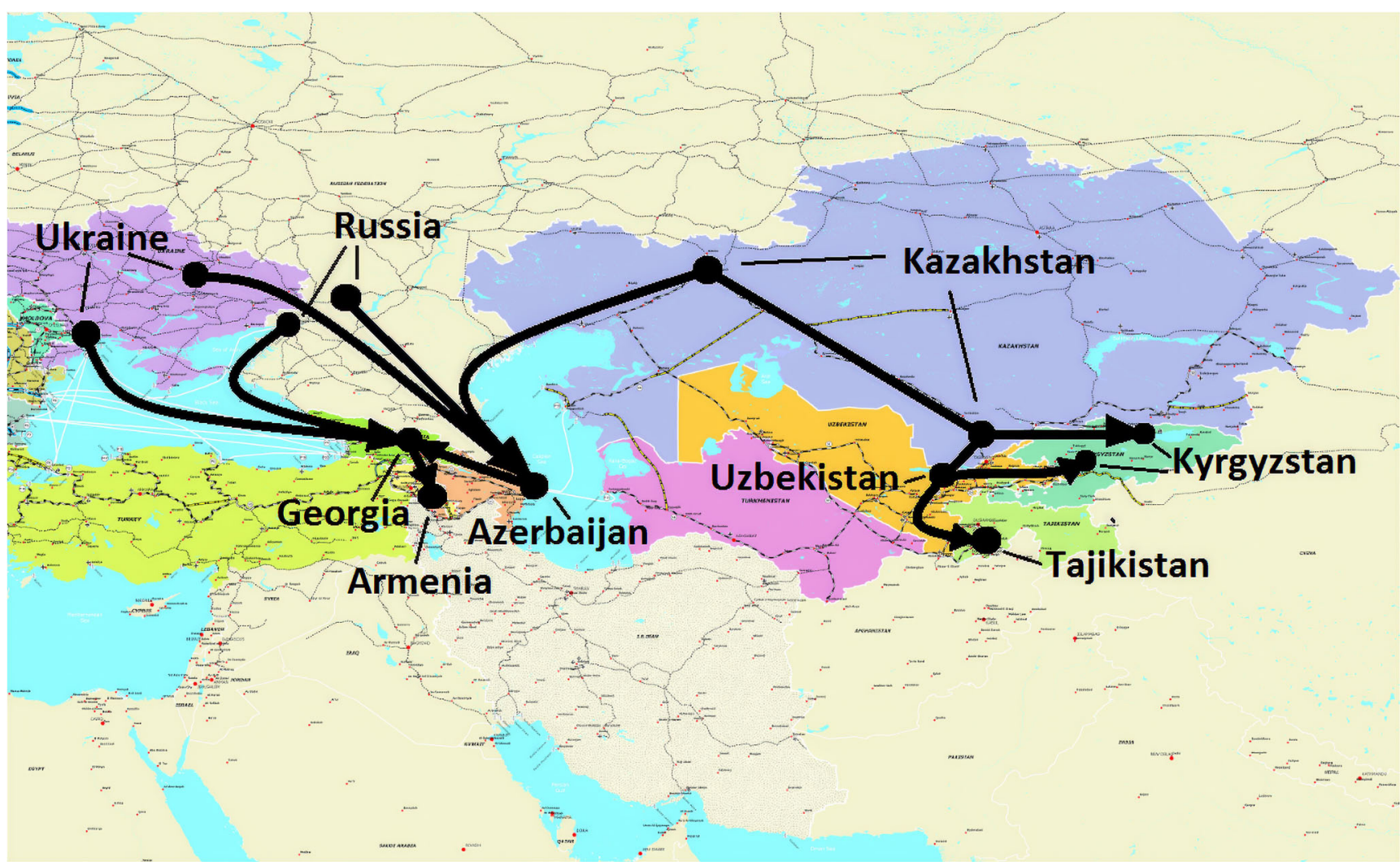

Fig. 2 Map of well-established wheat trade routes from the Black Sea region to Central Asia and the South Caucasus. Source: TRACECA (2017), authors' elaboration

In summary, while the levels of official grain transportation costs in Central Asia and the South Caucasus are similar, total transportation costs are substantially higher in Central Asia due to the high unofficial payments.

\section{Methodological framework and model estimation}

We investigated the relationships of wheat prices observed in countries in Central Asia and the South Caucasus with Black
Sea wheat export markets and world wheat markets in France and the USA within both linear and non-linear price transmission model frameworks.

\subsection{Methodological framework}

We assumed that prices in the spatially separated markets in the wheat import and export markets are linked by spatial price equilibrium, which is represented by

$P_{t}^{d}=\alpha+\beta P_{t}^{e}+\varepsilon_{t}$

Table 2 Wheat transport costs from the Black Sea region to Central Asia and the South Caucasus

\begin{tabular}{|c|c|c|c|c|c|c|c|c|c|c|c|}
\hline \multirow{3}{*}{$\begin{array}{l}\text { From } \\
\text { To }\end{array}$} & \multicolumn{5}{|l|}{ Kazakhstan } & \multirow{2}{*}{\multicolumn{3}{|c|}{$\frac{\text { Russia }}{\text { South Caucasus }}$}} & \multirow{2}{*}{\multicolumn{3}{|c|}{$\begin{array}{l}\text { Ukraine } \\
\text { South Caucasus }\end{array}$}} \\
\hline & \multicolumn{3}{|l|}{ Central Asia } & \multicolumn{2}{|c|}{ South Caucasus } & & & & & & \\
\hline & Kyrgyzstan & Tajikistan & Uzbekistan & Azerbaijan & Georgia & Armenia & Azerbaijan & Georgia & Armenia & Azerbaijan & Georgia \\
\hline Total transport costs & $80-135$ & $120-180$ & $60-110$ & $50-80$ & $70-110$ & $45-60$ & $20-40$ & $15-30$ & $45-60$ & $35-50$ & $15-30$ \\
\hline \multicolumn{12}{|c|}{ Breakdown of total costs: } \\
\hline Official rates & $30-70$ & $50-100$ & $30-60$ & $50-80$ & $70-110$ & $45-60$ & $20-40$ & $15-30$ & $45-60$ & $35-50$ & $15-30$ \\
\hline Unofficial payments & $50-65$ & $70-80$ & $30-50$ & - & - & - & - & - & - & - & - \\
\hline
\end{tabular}

$-=$ Not available. Transportation costs (USD/t) are approximate and average estimates. Sources: ADB (2006), Chabot and Tondel (2011), International Seaborne Market (2015), World Bank (2005), and expert interviews 
where $P_{t}^{d}$ and $P_{t}^{e}$ denotes the natural logarithm of domestic and regional/world export prices and $\varepsilon_{t}$ is a stationary disturbance term. The long-run price equilibrium is characterized by the intercept $\alpha$ and the long-run price transmission elasticity $\beta$. If the prices in the domestic and regional or world markets are not in equilibrium, then traders will make use of this price difference by trade arbitrage and sell wheat on the market with the higher price level. Through price adjustment processes, prices are brought back to their price equilibrium level.

Since Central Asian and the South Caucasian countries are net wheat importers and wheat is traded only in one direction from the Black Sea region to those countries, the wheat price observed in a domestic market $\left(P^{d}\right)$ is considered the dependent variable and regional and world market export prices $\left(P^{e}\right)$ are exogenous variables. Therefore, in this study we used a one-equation error correction model (linear or non-linear) rather than a vector error correction model, which is a system of equations capable of addressing endogeneity. ${ }^{3}$

Unlike the linear error correction model, the threshold error correction model explicitly accounts for the role of transaction costs. According to the spatial trade arbitrage theory (Goodwin and Piggott 2001), trade arbitrage between two spatially separated markets will take place only if the price difference exceeds transaction costs. Thus, a "regime dependent" price adjustment process may be observed, which can be depicted in a threshold error correction model, where the threshold corresponds to the size of transaction costs.

We used linear (Engle and Granger 1987) and threshold (Hansen and Seo 2002) cointegration tests to identify the existence of spatial price equilibrium and to determine whether the price adjustment mechanism is of a linear or non-linear type.

If the price series are linearly cointegrated, then a linear error correction model developed by Engle and Granger (1987) is estimated to quantify the short-run price dynamics in the next step

$\Delta P_{t}^{d}=\gamma \varepsilon_{t-1}+\sum_{i=1}^{k} \delta_{i} \Delta P_{t-i}^{d}+\sum_{i=1}^{k} \theta_{i} \Delta P_{t-i}^{e}+\omega_{t}$

where $\Delta$ is the first difference operator and $\varepsilon_{t-1}$ represents the error correction term (ECT) variable which is equal to the residuals from eq. [1] lagged by one period. $\gamma$ denotes the speed of adjustment parameter which measures the speed at which deviations from the long-run equilibrium are corrected

\footnotetext{
${ }^{3}$ In addition to single-equation models, we also used a vector error correction model to examine the sensitivity of the estimated model parameters. Confirming our assumption of "small, open economies", the estimation results of the vector error correction model (not reported in this study) indicated that only domestic prices are adjusting to restore price equilibrium between domestic and export markets. We also found the magnitude of the estimated price transmission parameters barely different across the two types of models, further justifying that our chosen model with a single equation did not suffer from endogeneity.
}

by trade arbitrage. $\Delta P_{t-i}^{d}$ and $\Delta P_{t-i}^{e}$ represent lagged values of the first difference of the domestic and regional/world price series of lags $i=1, \ldots, k$, ensuring that the model residuals are serially uncorrelated. $\delta_{i}$ and $\theta_{i}$ contain dynamic short-run parameters; $\omega_{t}$ is a conventional residual term with $\omega_{t} \sim \mathrm{N}\left(0, \sigma^{2}\right)$.

If threshold cointegration is identified between prices, then we estimate the threshold error correction model. Since wheat trade between a wheat importing and a wheat exporting country is uni-directional, we applied a model framework with one threshold and two regimes

$\Delta P_{t}^{d}=\left\{\begin{array}{ccc}\gamma_{1} \varepsilon_{t-1}+\sum_{i=1}^{k} \delta_{1 i} \Delta P_{t-i}^{d}+\sum_{i=1}^{k} \theta_{1 i} \Delta P_{t-i}^{e}+\omega_{1 t}, & \varepsilon_{t-1} \leq \tau & \text { Binner^regime } \\ \gamma_{2} \varepsilon_{t-1}+\sum_{i=1}^{k} \delta_{2 i} \Delta P_{t-i}^{d}+\sum_{i=1}^{k} \theta_{2 i} \Delta P_{t-i}^{e}+\omega_{2 t}, & \varepsilon_{t-1}>\tau & \text { Bouter }{ }^{\wedge} \text { regime }\end{array}\right.$

where $\tau$ denotes the threshold value estimated by the model. The error correction term $\varepsilon_{t-1}$ serves as a threshold variable as well. The parameter $\tau$ is interpreted as an estimate of transaction costs from the world market to the domestic markets. It includes not only observed transportation costs and customs clearance, but also other unobserved costs, such as physical and institutional infrastructure, ease of accessing market information, and price discounts or premiums paid due to quality differences.

In a threshold error correction model, the threshold variable $\varepsilon_{t-1}$ and corresponding threshold parameter $\tau$ determine the state of the regime $r, r=1,2$. If the magnitude of deviation from the long-run equilibrium is larger than the size of threshold, then the ECT observations are attributed to the "outer" regime $(r=2)$, where strong price adjustment takes place corresponding to the profitable trade arbitrage. However, if the magnitude of disequilibrium, expressed by $\varepsilon_{t-1}$ term, does not exceed the size of threshold, then observations are attributed to the "inner" regime $(r=1)$, where the speed of adjustment is much weaker or price adjustment does not occur at all (prices may move independently of each another due to the unprofitability of trade arbitrage).

To obtain threshold parameters, we applied the regularized Bayesian estimator recently developed by Greb et al. (2013) instead of the classic profile likelihood estimator (Hansen and Seo 2002; Lo and Zivot 2001). ${ }^{4}$ The former is superior due to its better small sample properties and avoidance of arbitrary trimming parameter to generate a threshold estimate. As a result, the Bayesian threshold estimate is well-defined over the entire domain of the threshold parameter. In contrast, a profile likelihood estimator requires a trimming of sample observations to ensure sufficient degrees of freedom for the estimation of model parameters. This procedure might lead to

\footnotetext{
${ }^{4}$ We are grateful to Friederike Greb for supplying her R script on the estimation of the threshold vector error correction model (with two thresholds) through an improved regularized Bayesian estimator. We modified the original code to adjust it to the threshold error correction model representation with one threshold and no constant, as given in equation [3].
} 
biased model estimation results if the true value of threshold parameters is excluded from the sample. The regularized Bayesian technique, on the other hand, succeeds in retaining all sample observations in the estimation process by penalizing differences between regimes and keeping them small when data contain little information.

Though an error correction model became the benchmark in examining spatial price linkages and market integration in empirical studies, this model approach yet faces several limitations. First, it is based on the assumption that transaction costs are stationary over time and are equal to a constant proportion of commodity prices. On the other hand, if this assumption fails, implying that actual transaction costs are indeed nonstationary, then the lack of linear or threshold cointegration can be wrongly interpreted as evidence of market inefficiencies (Fackler and Goodwin 2001). Second, the spatial price transmission analysis does not account for the actual trade flows and transaction costs data (Barrett 1996). The parity bounds model is an alternative approach to studying market integration with actual transportation costs being accounted for; however, as continuous times series data on transportation costs are not available for Central Asia and the South Caucasus, we use more parsimonious price transmission models, allowing us to analyze market integration based on the price series data only. Third, we conducted a price transmission analysis in a bivariate setup, allowing for a pairwise price analysis only, whereas several prices at different locations across space may also be simultaneously determined, which can be analyzed within a multivariate price transmission model. Nonetheless, the multivariate analysis of spatial price linkages so far has only been possible for the linear modelling of price linkages. In contrast, the analysis of the spatial integration of grain markets, particularly in Central Asia, explicitly requires accounting for the influence of trade costs, which is achieved by using the threshold error correction model, which can only be implemented in a bivariate setup.

\subsection{Model estimation}

Initially, we estimated the parameters of the long-run price equilibrium [1] by the ordinary least squares (OLS) method.

If the price series were cointegrated, we applied the linear error correction model framework following Engle and Granger's (1987) approach. If the price series were cointegrated in a non-linear fashion, we then estimated the threshold error correction model (Greb et al. 2013).

Next, the threshold parameters in eq. [3] were identified using the regularized Bayesian technique. A function to choose the optimal threshold value of ECTs is called the posterior median and is constructed as follows:

$\int_{\min \left(\varepsilon_{t-1}\right)}^{\hat{\tau}_{r} B} P_{r B}(\tau \mid \Delta P, X) d \tau=0.5$

where $X$ is a $n \times d$ matrix that compactly stacks together columns of ECTs and values of lagged terms. $P_{r B}(\tau \mid \Delta P, X)$ denotes marginal posterior density, which is well defined across the space of all possible threshold parameter $T=\left\{\tau \mid \min \left(\varepsilon_{t-1}\right)\right.$ $\left.<\tau<\max \left(\varepsilon_{t-1}\right)\right\}$. In the previous expression, $\tau$ is the optimal threshold that separates the space into two regimes and satisfies the requirement that $\tau>0$. Computation is based on a prior $P_{r B}(\tau \mid X) \propto I(\tau \in T)$ for $\tau$, where $I(\cdot)$ is an indicator function providing for switching between regimes.

Lastly, in choosing a threshold estimate, we estimated the additional short-run price transmission parameters of the threshold error correction model in eq. [3] separately in "outer" and "inner" regimes with the restricted maximum likelihood method that is implemented through mixedeffects modelling using an "nlme" package in R (Pinheiro et al. 2017).

\section{Data and data properties}

This section provides an overview of the sources and characteristics of the wheat prices, which served as the basis for our price transmission and volatility analysis.

\subsection{Data}

We used a unique database covering wheat prices for 11 countries (Table 3). As pointed out above, suitable wheat price data for the import-dependent countries is scarce. Price data are often simply not available publicly, as in Uzbekistan, for example, or it can be accessed only through personal contacts, as in the case of Azerbaijan. The national statistics agency of Uzbekistan does not monitor wheat price data. The data that we used in our analysis was directly gathered during 2001 and 2009 at the central retail market in Urgench (Khorezm region) within the KHOREZEM project. These data were collected in a consistent and systematic way as part of a more comprehensive database of the project. ${ }^{5}$

Our data set comprised 95 observations for each price series covering the period from October 2006 to August 2014 (Table 3). One exception was the data for Uzbekistan, which comprised 39 observations of wheat price series for the period from October 2006 to December 2009.

We used retail prices for the analysis of the integration of grain markets in Central Asia and producer and import prices

\footnotetext{
${ }^{5}$ Mori Clement et al. (2014) discuss the project data in detail; the project website www.zef.de/khorezm provides more information on the project itself.
} 
Table 3 Data description on wheat prices in the South Caucasus, Central Asia and Black Sea areas

\begin{tabular}{|c|c|c|c|c|}
\hline & & Country & Price & Sata source \\
\hline \multirow[t]{6}{*}{ Domestic wheat price } & \multirow[t]{3}{*}{ South Caucasus } & Armenia & Producer price, $\mathrm{AMD} / \mathrm{t}$ & Statistics office \\
\hline & & Azerbaijan & Producer price, AZN/t & Statistics office \\
\hline & & Georgia & Import price (CIF), GEL/t & Statistics office \\
\hline & \multirow[t]{3}{*}{ Central Asia } & Kyrgyzstan & Retail price, KGS/t & WFP \\
\hline & & Tajikistan & Retail price, TJS/t & WFP \\
\hline & & Uzbekistan & Retail price, UZS/t & ZEF/UNESCO \\
\hline \multirow[t]{6}{*}{ Export wheat price } & \multirow[t]{4}{*}{ Black Sea } & Kazakhstan_s & Export price (FOB), USD/t & Kazakh-Zerno \\
\hline & & Kazakhstan_n & Export price (FOB), USD/t & APK-Inform \\
\hline & & Russia & Export price (FOB), USD/t & APK-Inform \\
\hline & & Ukraine & Export price (FOB), USD/t & APK-Inform \\
\hline & \multirow[t]{2}{*}{ Reference markets } & France & Export price (FOB), USD/t & HGCA \\
\hline & & USA & Export price (FOB), USD/t & USDA \\
\hline
\end{tabular}

for the grain markets in the South Caucasus. Using the various types of wheat prices may influence the size of parameter estimates to some degree. In particular, attributable to the differences in price levels at the various stages of the supply chain, an analysis with retail prices may result in the underestimation of the long-run price transmission parameter and the speed of adjustment parameter compared to the parameter estimated with producer or import prices. Contrastingly, thresholds for price pairs including retail prices are overestimated compared to price pairs with producer and import prices. The domestic prices in the Georgian grain market are well represented by the wheat import (CIF) prices since more than $90 \%$ of total wheat supplied on the domestic market is imported.

We used wheat export prices observed in northern Kazakhstan to serve as the reference price for the South Caucasian importing countries. In addition, a wheat export price observed in southern Kazakhstan was used as the reference price for exports to the neighboring Central Asian countries.

Wheat export prices for Russia and Ukraine have 15 and 16 missing observations, accounting for $16 \%$ and $17 \%$ of the sample, respectively. Export prices were not observed when wheat trade was limited by wheat export restrictions in both countries. The effect of export restrictions on wheat prices in Russia and Ukraine is addressed by Götz et al. (2013, 2016). In order to create a continuous time series, the missing observations were filled using a linear imputation technique, making use of the Kazakh wheat export price, which is highly correlated with the Russian and Ukrainian prices. Since wheat trade is usually priced in US dollars, all local wheat price series were transformed to this currency.

From this database, we built 30 bivariate price pairs, each consisting of a domestic price of six importing countries and an exporting price of five exporting countries (Fig. 3). We used the Kazakh wheat export price of the northern region with price pairs including the domestic price in a South Caucasian country. Additionally, we built three price pairs by combining the domestic price of a Central Asian country with a southern Kazakhstan wheat export price.

\subsection{Data properties}

Figure 4 indicates that, on average, the median and variation of the domestic wheat prices in Central Asian countries are higher than in the South Caucasian countries. Relatively high price levels are typical for domestic markets in landlocked countries. However, high price levels observed in Central Asia might be explained in part by the type of wheat prices in the three Central Asian countries: they are retail prices for domestically grown wheat. They contrast with the wheat prices in Armenia and Azerbaijan, which are producer prices; in Georgia, the reported domestic wheat price level is the CIF import price.

In addition, wheat quality and the variability of yields from year to year might influence the distributional characteristics of wheat prices. For instance, the relatively low median domestic wheat price in Tajikistan may correlate with the generally low quality of domestically grown wheat due to unfavorable climatic conditions and lack of irrigation systems, whereas wheat produced in Kyrgyzstan is of relatively higher quality.

The lowest median wheat price was also observed in Uzbekistan, where domestic wheat production is highly supported by the government, but, as noted previously, farmers must also sell a portion of their wheat to state-owned enterprises at relatively low prices fixed by the government.

The domestic wheat price in Armenia, the landlocked country in the South Caucasus that cannot trade directly with Azerbaijan due to an active military conflict, represents the third highest median price. This contrasts with Georgia, whose Black Sea ports provide direct access to the world market, 

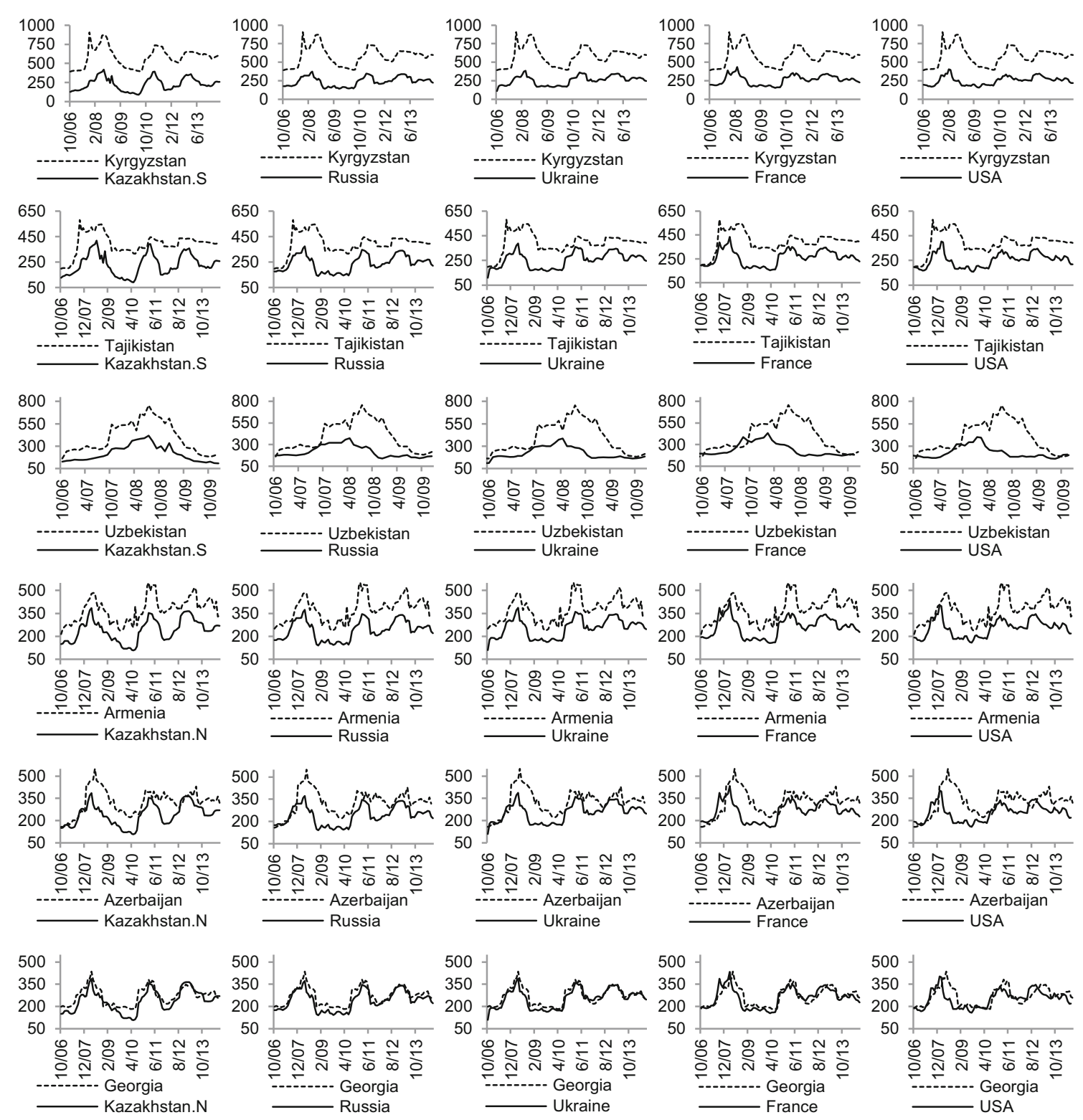

Fig. 3 Analyzed wheat price pairs for exporting and importing countries. Source: See Table 3

Fig. 4 Boxplot of wheat price series for (a) domestic prices in wheat importing countries and (b) export prices in wheat exporting countries
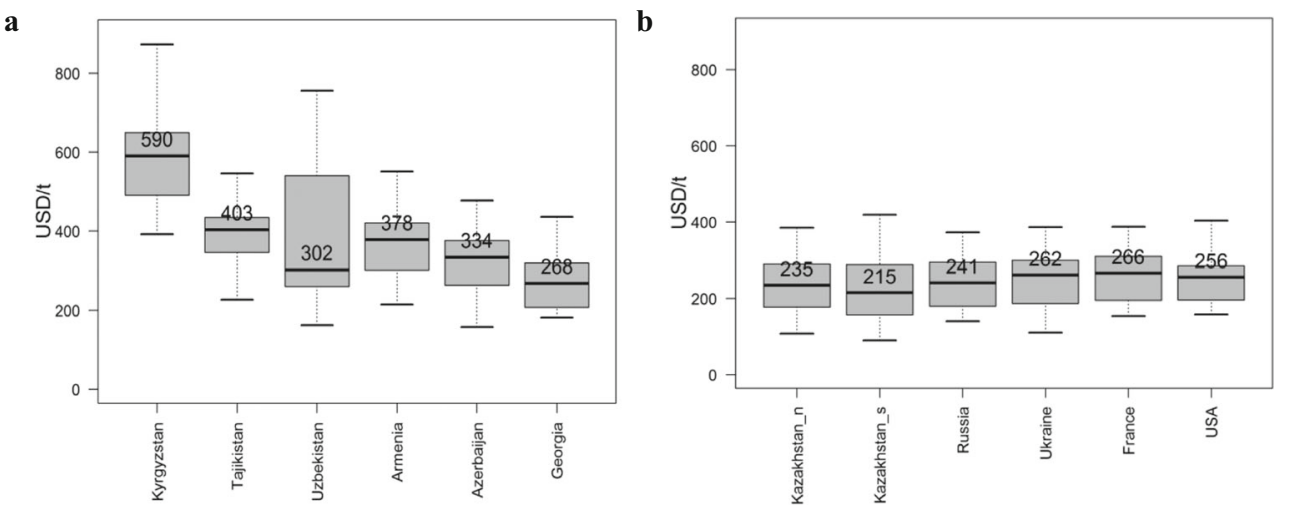
where the wheat price is characterized by the lowest median value and least price variation.

The distribution of wheat prices in the wheat exporting countries was much more homogeneous. Minor differences in median values across countries might be explained by varying wheat quality grades. For example, the median export price was the highest for wheat of grade one from France, followed by wheat of grade two exported from the USA, and then exports of mostly wheat of grade three from Russia.

The interquartile range and amplitude of wheat price variation was the widest and the median was the lowest for wheat export prices in southern Kazakhstan when compared with the northern region or even other wheat exporting countries. We suspect that the volatile market situation in Central Asian importing countries is influencing export price formation in southern Kazakhstan, as reflected in a relatively large interquartile range. Also, due to the low consumer income levels in the Central Asian countries, the quality of the wheat exported to the Central Asian countries may be lower, as reflected by the lower median wheat price in southern Kazakhstan compared to that in northern Kazakhstan.

A further basic characteristic of the wheat price series was their volatility, indicating the degree of risk that prevails in the wheat markets. High price volatility results in suboptimal level of production, increasing production costs, and reducing incentives for investments. Historical price volatility of each individual price series is measured non-parametrically as the standard deviation $\left(\sigma_{i}\right)$ of the returns of a price series given as:

$\sigma_{i}=100 \sqrt{1 / T \sum_{t=1}^{T}\left(p_{i t}-\bar{p}_{i}\right)}$

where $p_{i t}$ denotes price return in time $t$ for country $i$ calculated as $p_{i t}=\ln \left(P_{i t} / P_{i t-1}\right)$ with $P_{i t}$ being the price of wheat expressed in USD/t and $\bar{p}_{i}$ denoting the mean of price returns for country $i: \bar{p}_{i}=\frac{1}{T} \sum_{t=1}^{T} p_{i t}$.

We found price volatility in domestic markets during the period 2006-2014 to be the highest in Central Asian countries, whereas it was significantly lower in South Caucasian countries (Fig. 5). This might be explained by the relatively inelastic wheat supply, which is characteristic for the markets in the landlocked Central Asian import-dependent countries. In those countries, grain storage facilities are extremely limited (World Bank 2011) and access to international grain markets incurs high transportation costs.

\section{Empirical results}

To specify a suitable price transmission model framework for each selected price pair, the existence of a meaningful spatial price equilibrium needs to be confirmed. Therefore, we tested all price series for the existence of a unit root and the price pairs for the presence of linear and threshold cointegration. In section 5.1 we present and interpret the results of the unit root and cointegration tests. This is followed by section 5.2 with the estimated parameters of the price transmission models for 24 out of 30 analyzed price pairs evaluated against a background of comprehensive qualitative knowledge of the wheat markets in those countries.

\subsection{Test on the existence of a unit root and cointegration}

Results of the ADF test ${ }^{6}$ (Dickey and Fuller 1981) suggested that all wheat prices contained a unit root in level and were stationary in first differences at the 5\% level of significance. Results of a traditional unit root test will be biased towards non-stationarity if structural breaks resulting from, for example, policy changes or macroeconomic shocks are ignored in the time series. Therefore, we conducted the breakpoint ADF test (Perron and Vogelsang 1992) to account for the possible influence of export restrictions implemented in the grain export markets of the Black Sea region in 2007-08 and 2010 11. Results indicate that all price series again contained a unit root at the $10 \%$ level of significance, confirming that all price series are integrated of order one.

Since the price series were identified as non-stationary, cointegration of the price pairs is required to keep the estimated spatial price equilibrium regression from being spurious but instead meaningful (Granger and Newbold 1974).

We applied the linear cointegration test by Engle and Granger (1987) ${ }^{7}$ with the null hypothesis of no cointegration against an alternative of linear cointegration. We also applied the threshold cointegration test by Hansen and Seo (2002), which examines threshold cointegration within a onethreshold model corresponding to the market setup in Central Asia and the South Caucasus (compare section 3.1).

The Engle and Granger's test confirmed linear cointegration for all price pairs containing a domestic wheat price of a South Caucasian country at the 5\% level of significance (Table 4). However, Engle and Granger's test suggests linear cointegration in just seven out of 15 cases for all price pairs that contain a domestic price of a Central Asian country. Especially, the domestic price series in Kyrgyzstan and Tajikistan were linearly cointegrated with the regional wheat export prices in southern Kazakhstan and the world wheat prices in France and the USA. Furthermore, linear cointegration was not verified for any of the price pairs that include Uzbekistan's domestic wheat price. One exception

\footnotetext{
${ }^{6}$ Results are available from the authors upon request.

${ }^{7}$ We view the Engle and Granger test as more suitable for evaluating linear cointegration compared to Johansen's (1988) test of linear cointegration. We explain this by analyzing wheat market pairs with one-directional trade flows (see section 4.1).
} 
Fig. 5 Wheat price volatility in wheat importing and exporting countries

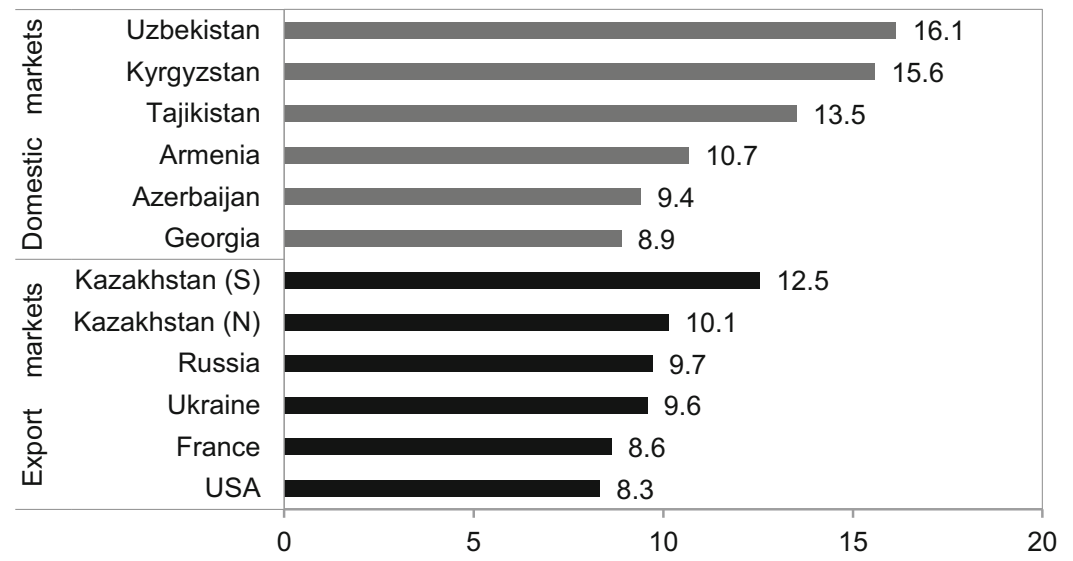

was the price pair Uzbekistan-southern Kazakhstan, which we found to be linearly cointegrated.

Like the results of the linear cointegration test, the Hansen and Seo test on threshold cointegration indicated linear cointegration at the $5 \%$ level of significance for all price pairs containing a domestic wheat price of a South Caucasian country (Table 4). In contrast, for the price pairs containing prices from Kyrgyzstan and Kazakhstan, Kyrgyzstan and Russia, Tajikistan and Kazakhstan, and Tajikistan and Russia, this test suggested threshold cointegration at the $5 \%$ level of significance. Threshold cointegration could not be confirmed for the 11 other price pairs constructed by combining a Central Asian domestic wheat price with an export market's wheat price.

With the results of the linear and threshold cointegration tests, we formed the cointegration patterns for the 30 price pairs presented in Table 5. All price pairs involving a wheat price of a South Caucasian country were cointegrated linearly, suggesting that domestic prices adjust uniformly to changes in an export price regardless of the level of trade costs.

By contrast, threshold cointegration was identified between wheat prices of Kyrgyzstan and Kazakhstan, Kyrgyzstan and Russia, Tajikistan and Kazakhstan, and Tajikistan and Russia. This suggests that, in contrast to the South Caucasus, transaction costs play a much larger role in the comovement of Central Asian domestic wheat prices with export prices in regional markets.

Furthermore, the threshold cointegration test did not indicate the presence of threshold effects in price relationships between domestic wheat prices in Central Asia and the South Caucasus and world export prices in France and the USA. Due to the vast distances involved and lack of wellestablished transportation infrastructure, transportation costs are prohibitive, thus discouraging wheat imports to Central Asia and the South Caucasus from those internationally important wheat exporting countries. ${ }^{8}$

\footnotetext{
${ }^{8}$ As an exception, some grain imports from European countries are observed in South Caucasus countries during wheat export restrictions from Kazakhstan, Russia, and Ukraine (compare section 2).
}

On the other hand, just as in the countries of the South Caucasus, in Central Asian Kyrgyzstan and Tajikistan, domestic wheat prices were linearly cointegrated with the world wheat prices in France and the USA, highlighting the importance of information flows from the international to domestic wheat markets.

Neither linear nor threshold cointegration was established between domestic wheat prices in Central Asia and the wheat export prices in Ukraine. In contrast to prices in the South Caucasus, which we found to be linearly cointegrated with the Ukrainian wheat export prices, Central Asian countries do not import wheat from Ukraine because of the relatively long distance between the countries (compare Fig. 1).

Compared with the other Central Asian countries, empirical evidence on wheat market integration was the weakest for Uzbekistan. We found the Uzbek wheat price to be linearly cointegrated solely with the wheat export price in southern Kazakhstan. Long-run price equilibrium was not established between Uzbekistan and any other export market in the Black Sea region or international markets. This may be explained by the fact that the Uzbek wheat market is one of the most comprehensively regulated markets in Central Asia, with governmental input cost subsidies, wheat price controls, and state grain buying programs, among others.

\subsection{Price transmission model estimation results}

We analyzed the price relationships between selected domestic wheat prices in Central Asia and the South Caucasus and export prices in the Black Sea and international markets within linear and threshold error correction model frameworks. The price transmission model estimates were evaluated for characteristics of spatial price equilibrium and error correction behavior, with the role of trade costs explicitly accounted for. 
Table 4 Tests of linear and threshold cointegration

\begin{tabular}{|c|c|c|c|}
\hline \multirow[t]{2}{*}{ Price series } & \multicolumn{2}{|c|}{ Engle and Granger test ${ }^{a}$} & \multirow{2}{*}{$\begin{array}{l}\text { Hansen and Seo test ( } 1 \text { threshold) }{ }^{b} \\
p \text {-value }\end{array}$} \\
\hline & Test statistic & $p$-value & \\
\hline $\mathrm{P}_{\mathrm{t}}^{\mathrm{arm}}-\mathrm{P}_{\mathrm{t}}^{\mathrm{kaz} \_n}$ & $-4.051^{* * *}$ & 0.001 & 0.625 \\
\hline $\mathrm{P}_{\mathrm{t}}^{\mathrm{arm}}-\mathrm{P}_{\mathrm{t}}^{\text {rus }}$ & $-3.723^{* * * *}$ & $<0.001$ & 0.128 \\
\hline $\mathrm{P}_{\mathrm{t}}^{\mathrm{arm}}-\mathrm{P}_{\mathrm{t}}^{\mathrm{ukr}}$ & $-3.614^{* * *}$ & $<0.001$ & 0.385 \\
\hline $\mathrm{P}_{\mathrm{t}}^{\mathrm{arm}}-\mathrm{P}_{\mathrm{t}}^{\mathrm{frn}}$ & $-3.545^{* * *}$ & 0.001 & 0.114 \\
\hline $\mathrm{P}_{\mathrm{t}}^{\mathrm{arm}}-\mathrm{P}_{\mathrm{t}}^{\text {usa }}$ & $-3.800^{* * * *}$ & $<0.001$ & 0.796 \\
\hline $\mathrm{P}_{\mathrm{t}}^{\mathrm{azn}}-\mathrm{P}_{\mathrm{t}}^{\mathrm{kaz} \_n}$ & $-3.050^{* * * *}$ & 0.003 & 0.128 \\
\hline $\mathrm{P}_{\mathrm{t}}^{\mathrm{azn}}-\mathrm{P}_{\mathrm{t}}^{\text {rus }}$ & $-2.731^{* * * *}$ & 0.007 & 0.251 \\
\hline $\mathrm{P}_{\mathrm{t}}^{\mathrm{azn}}-\mathrm{P}_{\mathrm{t}}^{\mathrm{ukr}}$ & $-2.429^{* * *}$ & 0.015 & 0.793 \\
\hline $\mathrm{P}_{\mathrm{t}}^{\mathrm{azn}}-\mathrm{P}_{\mathrm{t}}^{\mathrm{frn}}$ & $-2.674^{* * * *}$ & 0.008 & 0.817 \\
\hline $\mathrm{P}_{\mathrm{t}}^{\mathrm{azn}}-\mathrm{P}_{\mathrm{t}}^{\text {usa }}$ & $-2.775^{* * * *}$ & 0.006 & 0.772 \\
\hline $\mathrm{P}_{\mathrm{t}}^{\mathrm{geo}}-\mathrm{P}_{\mathrm{t}}^{\mathrm{kaz} \_\mathrm{n}}$ & $-4.783^{* * * *}$ & $<0.001$ & 0.786 \\
\hline $\mathrm{P}_{\mathrm{t}}^{\text {geo }}-\mathrm{P}_{\mathrm{t}}^{\text {rus }}$ & $-4.123^{* * * *}$ & $<0.001$ & 0.610 \\
\hline $\mathrm{P}_{\mathrm{t}}^{\mathrm{geo}}-\mathrm{P}_{\mathrm{t}}^{\mathrm{ukr}}$ & $-4.739^{* * * *}$ & $<0.001$ & 0.234 \\
\hline $\mathrm{P}_{\mathrm{t}}^{\mathrm{geo}}-\mathrm{P}_{\mathrm{t}}^{\mathrm{frn}}$ & $-3.729^{* * * *}$ & $<0.001$ & 0.670 \\
\hline $\mathrm{P}_{\mathrm{t}}^{\text {geo }}-\mathrm{P}_{\mathrm{t}}^{\text {usa }}$ & $-3.601^{* * * *}$ & $<0.001$ & 0.568 \\
\hline $\mathrm{P}_{\mathrm{t}}^{\mathrm{kyr}}-\mathrm{P}_{\mathrm{t}}^{\mathrm{kaz} \_\mathrm{s}}$ & $-2.893^{* * * *}$ & 0.004 & 0.021 \\
\hline $\mathrm{P}_{\mathrm{t}}^{\mathrm{kyr}}-\mathrm{P}_{\mathrm{t}}^{\text {rus }}$ & -2.501 & 0.327 & 0.011 \\
\hline $\mathrm{P}_{\mathrm{t}}^{\mathrm{kyr}}-\mathrm{P}_{\mathrm{t}}^{\mathrm{ukr}}$ & -2.476 & 0.125 & 0.451 \\
\hline $\mathrm{P}_{\mathrm{t}}^{\mathrm{kyr}}-\mathrm{P}_{\mathrm{t}}^{\mathrm{frm}}$ & $-2.539^{* *}$ & 0.012 & 0.473 \\
\hline $\mathrm{P}_{\mathrm{t}}^{\mathrm{kyr}}-\mathrm{P}_{\mathrm{t}}^{\mathrm{usa}}$ & $-2.482^{* *}$ & 0.013 & 0.265 \\
\hline $\mathrm{P}_{\mathrm{t}}^{\mathrm{taj}}-\mathrm{P}_{\mathrm{t}}^{\mathrm{kaz} \_\mathrm{s}}$ & $-2.972^{* *}$ & 0.041 & 0.033 \\
\hline $\mathrm{P}_{\mathrm{t}}^{\mathrm{taj}}-\mathrm{P}_{\mathrm{t}}^{\mathrm{rus}}$ & -2.688 & 0.244 & 0.020 \\
\hline $\mathrm{P}_{\mathrm{t}}^{\mathrm{taj}}-\mathrm{P}_{\mathrm{t}}^{\mathrm{ukr}}$ & -2.094 & 0.248 & 0.644 \\
\hline $\mathrm{P}_{\mathrm{t}}^{\mathrm{taj}}-\mathrm{P}_{\mathrm{t}}^{\mathrm{frn}}$ & $-2.818^{* * * *}$ & 0.005 & 0.172 \\
\hline $\mathrm{P}_{\mathrm{t}}^{\mathrm{taj}}-\mathrm{P}_{\mathrm{t}}^{\text {usa }}$ & $-2.902^{* *}$ & 0.049 & 0.595 \\
\hline $\mathrm{P}_{\mathrm{t}}^{\mathrm{uzb}}-\mathrm{P}_{\mathrm{t}}^{\mathrm{kaz} \_\mathrm{s}}$ & -3.904 & 0.005 & 0.603 \\
\hline $\mathrm{P}_{\mathrm{t}}^{\mathrm{uzb}}-\mathrm{P}_{\mathrm{t}}^{\text {rus }}$ & -2.038 & 0.270 & 0.909 \\
\hline $\mathrm{P}_{\mathrm{t}}^{\mathrm{uzb}}-\mathrm{P}_{\mathrm{t}}^{\mathrm{ukr}}$ & -1.526 & 0.510 & 0.379 \\
\hline $\mathrm{P}_{\mathrm{t}}^{\mathrm{uzb}}-\mathrm{P}_{\mathrm{t}}^{\mathrm{frn}}$ & -1.905 & 0.327 & 0.786 \\
\hline $\mathrm{P}_{\mathrm{t}}^{\mathrm{uzb}}-\mathrm{P}_{\mathrm{t}}^{\text {usa }}$ & -1.838 & 0.357 & 0.526 \\
\hline
\end{tabular}

${ }^{a} \mathrm{H}_{0}$ : no cointegration $\mid \mathrm{H}_{1}$ : linear cointegration. Test is applied to the regression residuals from cointegration equations. One-sided p-values are from MacKinnon (1996). Lag length selection is based on Schwarz Information Criterion. ${ }^{\mathbf{b}} \mathrm{H}_{0}$ : linear cointegration $\mid \mathrm{H}_{1}$ : threshold cointegration. Trimming parameter is equal to 0.05 ; number of bootstrap replications is set to 1000 ; fixed regressor bootstrap method. ${ }^{*} p<0.10,{ }^{* * *} p<0.05,{ }^{* * * *} p<0.01$

\subsubsection{Spatial price equilibrium}

In general, our results suggest that the comovement of domestic prices with export prices in the Black Sea region and world markets is stronger in the South Caucasus than in Central Asia (Table 6).

Price changes in the regional Black Sea wheat export markets were on average $16 \%$ more completely transmitted to domestic wheat prices in the South Caucasus $(0.63$ on average) as compared to Central Asia (0.47 on average). For example, if the wheat export price in southern Kazakhstan increases by $10 \%$, then the wheat price in Kyrgyzstan increases by $4.8 \%$. Comparing domestic markets across regions, price changes are again less strongly transmitted from the world to domestic markets in Central Asia, with the long-run price transmission elasticity ranging between 0.40 and 0.61 , compared to the South Caucasus, for which price transmission elasticity varies between 0.49 and 0.79 .

With respect to Central Asian countries, our results suggest that the wheat market in Uzbekistan is solely integrated with the wheat market in Kazakhstan, but segregated from the wheat export markets in Russia, Ukraine, France, and the USA. Specifically, wheat prices in Uzbekistan almost perfectly comove with wheat prices in southern Kazakhstan. This might be explained by the dominance of the Uzbek state-run enterprise that centralizes the trade of wheat (Bobojonov et al. 2017). 
Table 5 Cointegration patterns and selection of error correction models

\begin{tabular}{|c|c|c|c|}
\hline \multirow[t]{2}{*}{ Price series } & \multicolumn{2}{|c|}{ Cointegration pattern } & \multirow[t]{2}{*}{ Estimated error correction model (ECM) } \\
\hline & Linear & Threshold & \\
\hline $\mathrm{P}_{\mathrm{t}}^{\mathrm{arm}}-\mathrm{P}_{\mathrm{t}}^{\mathrm{kaz} \_\mathrm{n}}$ & $\checkmark$ & $\mathrm{x}$ & Linear ECM \\
\hline $\mathrm{P}_{\mathrm{t}}^{\mathrm{arm}}-\mathrm{P}_{\mathrm{t}}^{\mathrm{rus}}$ & $\checkmark$ & $\mathrm{x}$ & Linear ECM \\
\hline $\mathrm{P}_{\mathrm{t}}^{\mathrm{arm}}-\mathrm{P}_{\mathrm{t}}^{\mathrm{ukr}}$ & $\checkmark$ & $\mathrm{x}$ & Linear ECM \\
\hline $\mathrm{P}_{\mathrm{t}}^{\mathrm{arm}}-\mathrm{P}_{\mathrm{t}}^{\mathrm{frn}}$ & $\checkmark$ & $\mathrm{x}$ & Linear ECM \\
\hline $\mathrm{P}_{\mathrm{t}}^{\mathrm{arm}}-\mathrm{P}_{\mathrm{t}}^{\mathrm{usa}}$ & $\checkmark$ & $\mathrm{x}$ & Linear ECM \\
\hline $\mathrm{P}_{\mathrm{t}}^{\mathrm{azn}}-\mathrm{P}_{\mathrm{t}}^{\mathrm{kaz} \_n}$ & $\checkmark$ & $\mathrm{x}$ & Linear ECM \\
\hline $\mathrm{P}_{\mathrm{t}}^{\mathrm{azn}}-\mathrm{P}_{\mathrm{t}}^{\text {rus }}$ & $\checkmark$ & $\mathrm{x}$ & Linear ECM \\
\hline $\mathrm{P}_{\mathrm{t}}^{\mathrm{azn}}-\mathrm{P}_{\mathrm{t}}^{\mathrm{ukr}}$ & $\checkmark$ & $\mathrm{x}$ & Linear ECM \\
\hline $\mathrm{P}_{\mathrm{t}}^{\mathrm{azn}}-\mathrm{P}_{\mathrm{t}}^{\mathrm{frn}}$ & $\checkmark$ & $\mathrm{x}$ & Linear ECM \\
\hline $\mathrm{P}_{\mathrm{t}}^{\mathrm{azn}}-\mathrm{P}_{\mathrm{t}}^{\text {usa }}$ & $\checkmark$ & $\mathrm{x}$ & Linear ECM \\
\hline $\mathrm{P}_{\mathrm{t}}^{\mathrm{geo}}-\mathrm{P}_{\mathrm{t}}^{\mathrm{kaz} \_n}$ & $\checkmark$ & $\mathrm{x}$ & Linear ECM \\
\hline $\mathrm{P}_{\mathrm{t}}^{\mathrm{geo}}-\mathrm{P}_{\mathrm{t}}^{\text {rus }}$ & $\checkmark$ & $\mathrm{x}$ & Linear ECM \\
\hline$P_{t}^{g e o}-P_{t}^{u k r}$ & $\checkmark$ & $\mathrm{x}$ & Linear ECM \\
\hline$P_{t}^{g e o}-P_{t}^{f i n}$ & $\checkmark$ & $\mathrm{x}$ & Linear ECM \\
\hline $\mathrm{P}_{\mathrm{t}}^{\mathrm{geo}}-\mathrm{P}_{\mathrm{t}}^{\text {usa }}$ & $\checkmark$ & $\mathrm{x}$ & Linear ECM \\
\hline $\mathrm{P}_{\mathrm{t}}^{\mathrm{kyr}}-\mathrm{P}_{\mathrm{t}}^{\mathrm{kaz} \_s}$ & $\checkmark$ & $\nabla$ & Threshold ECM \\
\hline $\mathrm{P}_{\mathrm{t}}^{\mathrm{kyr}}-\mathrm{P}_{\mathrm{t}}^{\text {rus }}$ & $\mathrm{x}$ & $\nabla$ & Threshold ECM \\
\hline $\mathrm{P}_{\mathrm{t}}^{\mathrm{kyr}}-\mathrm{P}_{\mathrm{t}}^{\mathrm{ukr}}$ & $\mathrm{x}$ & $\mathrm{x}$ & None \\
\hline $\mathrm{P}_{\mathrm{t}}^{\mathrm{kyr}}-\mathrm{P}_{\mathrm{t}}^{\mathrm{frn}}$ & $\checkmark$ & $\mathrm{x}$ & Linear ECM \\
\hline $\mathrm{P}_{\mathrm{t}}^{\mathrm{kyr}}-\mathrm{P}_{\mathrm{t}}^{\mathrm{usa}}$ & $\checkmark$ & $\mathrm{x}$ & Linear ECM \\
\hline $\mathrm{P}_{\mathrm{t}}^{\mathrm{taj}}-\mathrm{P}_{\mathrm{t}}^{\mathrm{kaz} \_\mathrm{s}}$ & $\checkmark$ & $\nabla$ & Threshold ECM \\
\hline $\mathrm{P}_{\mathrm{t}}^{\mathrm{taj}}-\mathrm{P}_{\mathrm{t}}^{\mathrm{rus}}$ & $\mathrm{x}$ & $\nabla$ & Threshold ECM \\
\hline $\mathrm{P}_{\mathrm{t}}^{\mathrm{taj}}-\mathrm{P}_{\mathrm{t}}^{\mathrm{ukr}}$ & $\mathrm{x}$ & $\mathrm{x}$ & None \\
\hline $\mathrm{P}_{\mathrm{t}}^{\mathrm{taj}}-\mathrm{P}_{\mathrm{t}}^{\mathrm{fm}}$ & $\checkmark$ & $\mathrm{x}$ & Linear ECM \\
\hline $\mathrm{P}_{\mathrm{t}}^{\mathrm{taj}}-\mathrm{P}_{\mathrm{t}}^{\text {usa }}$ & $\checkmark$ & $\mathrm{x}$ & Linear ECM \\
\hline $\mathrm{P}_{\mathrm{t}}^{\mathrm{uzb}}-\mathrm{P}_{\mathrm{t}}^{\mathrm{kaz} \_\mathrm{s}}$ & $\checkmark$ & $\mathrm{x}$ & Linear ECM \\
\hline $\mathrm{P}_{\mathrm{t}}^{\mathrm{uzb}}-\mathrm{P}_{\mathrm{t}}^{\text {rus }}$ & $\mathrm{x}$ & $\mathrm{x}$ & None \\
\hline $\mathrm{P}_{\mathrm{t}}^{\mathrm{uzb}}-\mathrm{P}_{\mathrm{t}}^{\mathrm{ukr}}$ & $\mathrm{x}$ & $\mathrm{x}$ & None \\
\hline $\mathrm{P}_{\mathrm{t}}^{\mathrm{uzb}}-\mathrm{P}_{\mathrm{t}}^{\mathrm{frn}}$ & $\mathrm{x}$ & $\mathrm{x}$ & None \\
\hline $\mathrm{P}_{\mathrm{t}}^{\mathrm{uzb}}-\mathrm{P}_{\mathrm{t}}^{\mathrm{usa}}$ & $\mathrm{x}$ & $\mathrm{x}$ & None \\
\hline
\end{tabular}

"None" indicates that cointegration tests do not suggest linear or threshold cointegration; hence, estimations are not conducted for the respective price pairs

Among other Central Asian countries, the Kyrgyz wheat market $(0.48)$ is the most strongly integrated with the wheat market in Kazakhstan, followed by Tajikistan (0.40). Kazakh wheat is exported to Kyrgyzstan by a direct rail line through a common border, whereas Kazakh wheat is mainly exported to Tajikistan through Uzbekistan.

The Kyrgyz and Tajik markets are more strongly integrated with export markets in Russia than in Kazakhstan, although the amount of wheat imported by Kyrgyzstan and Tajikistan originating in Russia is negligible. Moreover, if Kyrgyzstan and Tajikistan import Russian wheat, then the railway passes through Kazakhstan, suggesting that the transportation costs of wheat from Russia are higher. Obviously, the domestic wheat prices observed in Kyrgyzstan and Tajikistan are more strongly influenced by the Russian wheat export price than by the wheat export price observed at the southern border of Kazakhstan.

Within the South Caucasus region, prices in Georgia's wheat market exhibit the strongest comovement with the export prices in the Black Sea grain exporting countries $(0.71$ on average), followed by prices in Armenia ( 0.63 on average). At the other end of the spectrum is Azerbaijan, with the weakest price comovement on average at 0.55 .

Specifically, price changes in the Russian export market are transmitted to the domestic wheat market in Georgia by $74 \%$, Armenia by $63 \%$, and Azerbaijan by $49 \%$.

Wheat price changes in Kazakhstan, compared with Russia's, are transmitted to a lesser degree to the wheat prices 
Table 6 Estimated parameters of the long-run price equilibrium

\begin{tabular}{|c|c|c|c|c|c|c|c|c|}
\hline Export markets & Kyrgyzstan & Tajikistan & Uzbekistan & Central Asia (avg.) & Armenia & Azerbaijan & Georgia & South Caucasus (avg.) \\
\hline \multicolumn{9}{|c|}{ a. Price transmission elasticity } \\
\hline Kazakhstan & 0.48 & 0.40 & 1.06 & & 0.55 & 0.55 & 0.62 & \\
\hline Russia & 0.54 & 0.45 & - & & 0.63 & 0.49 & 0.74 & \\
\hline Ukraine & - & - & - & & 0.71 & 0.62 & 0.77 & \\
\hline Black Sea (avg.) & 0.51 & 0.43 & - & 0.47 & 0.63 & 0.55 & 0.71 & 0.63 \\
\hline France & 0.57 & 0.49 & - & & 0.62 & 0.51 & 0.75 & \\
\hline USA & 0.61 & 0.59 & - & & 0.71 & 0.60 & 0.79 & \\
\hline World (avg.) & 0.59 & 0.54 & - & 0.57 & 0.67 & 0.56 & 0.77 & 0.67 \\
\hline \multicolumn{9}{|l|}{ b. Intercept } \\
\hline Kazakhstan & 3.78 & 3.80 & 0.25 & & 2.91 & 2.78 & 2.20 & \\
\hline Russia & 3.41 & 3.52 & - & & 2.48 & 3.08 & 1.53 & \\
\hline Ukraine & - & - & - & & 1.97 & 2.35 & 1.31 & \\
\hline Black Sea (avg.) & 3.60 & 3.66 & - & 3.63 & 2.45 & 2.74 & 1.68 & 2.29 \\
\hline France & 3.20 & 3.25 & - & & 2.45 & 2.92 & 1.42 & \\
\hline USA & 2.97 & 2.68 & - & & 2.01 & 2.43 & 1.22 & \\
\hline World (avg.) & 3.09 & 2.97 & - & 3.03 & 2.23 & 2.68 & 1.32 & 2.08 \\
\hline
\end{tabular}

$-=$ no cointegration relationship exists between the prices

in Armenia and Georgia, which is in line with the observed wheat transportation costs (compare Table 2).

Although transportation costs of wheat imports to Azerbaijan are higher from Kazakhstan compared to Russia, wheat prices in Azerbaijan comove more strongly with prices in Kazakhstan. This could be explained by the strong business ties between Kazakhstan and Azerbaijan, which indicates that bargaining, search and information costs, as well as other parts of transaction costs usually not subject to empirical investigation, are lower from Kazakhstan to Azerbaijan than from the other Black Sea export markets. Moreover, Azerbaijani importers prefer Kazakh wheat with its high protein content over Russian wheat, resulting in a higher share of wheat imports from Kazakhstan compared to Russia among total Azerbaijani wheat imports.

Estimation results also indicated that long-run price transmission from wheat markets in France and the USA to the South Caucasian and Central Asian wheat markets is as high from markets in the Black Sea region, or in some cases even higher. This result is striking since neither the South Caucasian nor Central Asian countries import wheat from France or the USA. The strong comovement with wheat prices in the USA can be explained by the dominating role of the USA Chicago Board of Trade wheat price for price formation in those markets. According to information provided by traders, the Chicago Board of Trade price data can usually be monitored by all market participants, and it serves as a benchmark against which prices generally are negotiated in the wheat trade.

Finally, the long-run price equilibrium is further characterized by the intercept parameter, which corresponds to the transaction costs of the wheat trade. Our results suggest larger intercept values for the price relationships involving Central Asian countries and the Black Sea regional exporters (3.63 on average) compared to those involving the South Caucasian countries (2.29 on average). This supports our previous findings (see section 2), indicating that total transportation costs are significantly higher in the landlocked countries of Central Asia than in the South Caucasus. Similarly, results of the threshold and linear cointegration tests suggest that trade costs play a large role in the wheat trade of the Central Asian countries.

The particularly low value of the intercept (1.68 on average) for the price pairs involving the wheat price in Georgia can be explained by Georgia's direct access to the Black Sea market via its own ports, and thus its generally lower transportation costs.

\subsubsection{Correction of the temporary disequilibrium}

Well-functioning markets are characterized by rapid correction of short-run deviations from the long-run spatial price equilibrium, which is reflected by the large value of the speed of adjustment parameter. Our results suggest that the speed of adjustment of prices in the South Caucasian countries is generally higher than in the Central Asian countries (Table 7).

Concerning Central Asian markets, the highest speed of price adjustment was identified for the wheat price in Uzbekistan, which corrects deviations from the long-run equilibrium with the export price in southern Kazakhstan at a speed of adjustment equal to 0.65 . We explain the very quick elimination of price disequilibrium in Uzbekistan by the country's centralized state trading system. Wheat prices in Kyrgyzstan 
Table 7 Estimated parameters of the short-run price transmission process

\begin{tabular}{|c|c|c|c|c|c|c|}
\hline \multicolumn{7}{|l|}{ a. Speed of adjustment } \\
\hline Export markets & Kyrgyzstan & Tajikistan & Uzbekistan & Armenia & Azerbaijan & Georgia \\
\hline \multirow[t]{2}{*}{ Kazakhstan } & $-0.10,-0.35^{* * *}$ & $-0.08^{* * *},-0.32^{* *}$ & $-0.65^{* * *}$ & $-0.26^{* * * *}$ & $-0.20^{* * *}$ & $-0.28^{* * *}$ \\
\hline & {$[0.07,0.08]$} & {$[0.04,0.07]$} & & {$[0.07]$} & {$[0.05]$} & {$[0.07]$} \\
\hline \multirow[t]{2}{*}{ Russia } & $-0.15^{* *},-0.18^{* * *}$ & $-0.11^{*},-0.13^{* * *}$ & - & $-0.31^{* * * *}$ & $-0.16^{* * *}$ & $-0.36^{* * *}$ \\
\hline & {$[0.06,0.06]$} & {$[0.04,0.06]$} & & {$[0.06]$} & {$[0.04]$} & {$[0.10]$} \\
\hline \multirow[t]{2}{*}{ Ukraine } & - & - & - & $-0.39^{* * *}$ & $-0.19^{* * * *}$ & $-0.38^{* * *}$ \\
\hline & & & & {$[0.07]$} & {$[0.04]$} & {$[0.13]$} \\
\hline Black Sea (avg.) & $-0.15,-0.27$ & $-0.10,-0.23$ & - & -0.32 & -0.18 & -0.34 \\
\hline \multirow[t]{2}{*}{ France } & $-0.15^{* * *}$ & $-0.12^{* * *}$ & - & $-0.28^{* * * *}$ & $-0.15^{* * *}$ & $-0.29^{* * *}$ \\
\hline & {$[0.05]$} & {$[0.04]$} & & {$[0.06]$} & {$[0.04]$} & {$[0.10]$} \\
\hline \multirow[t]{2}{*}{ USA } & $-0.13^{* * * *}$ & $-0.12^{* * * *}$ & - & $-0.28^{* * * *}$ & $-0.17^{* * *}$ & $-0.29^{* * *}$ \\
\hline & {$[0.04]$} & {$[0.04]$} & & {$[0.06]$} & {$[0.05]$} & {$[0.05]$} \\
\hline World (avg.) & -0.14 & -0.12 & - & -0.28 & -0.16 & -0.29 \\
\hline
\end{tabular}

b. Thresholds

$\begin{array}{lllll}\text { Export markets } & \text { Kyrgyzstan } & \text { Tajikistan } & \text { Uzbekistan } & \text { Central Asia (avg.) } \\ \text { Kazakhstan } & 0.17 & 0.21 & - & 0.19 \\ \text { Russia } & 0.18 & 0.24 & - & 0.21 \\ \text { Ukraine } & - & - & - & - \\ \text { Black Sea (avg.) } & 0.175 & 0.225 & - & 0.20\end{array}$

c. Percentage distribution of observations between regimes ("inner"; "outer")

$\begin{array}{lllll}\text { Export markets } & \text { Kyrgyzstan } & \text { Tajikistan } & \text { Uzbekistan } & \text { Central Asia (avg.) } \\ \text { Kazakhstan } & 90 \%, 10 \% & 95 \%, 5 \% & - & 92 \%, 8 \% \\ \text { Russia } & 88 \%, 12 \% & 90 \%, 10 \% & - & 89 \%, 11 \% \\ \text { Ukraine } & - & - & - & - \\ \text { Black Sea (avg.) } & 89 \%, 11 \% & 92 \%, 8 \% & - & 91 \%, 9 \%\end{array}$

$-=$ no cointegration relationship exists between the prices. Standard errors are shown in square brackets. ${ }^{*} \mathrm{p}<0.10,{ }^{* *} \mathrm{p}<0.05,{ }^{* * *} \mathrm{p}<0.01$

and Tajikistan both adjust price deviations from the price equilibrium with the Kazakh export prices more quickly (0.35 and 0.32 in the "outer regime") than with the Russian export prices ( 0.18 and 0.13 in the "outer" regime). We trace this pattern of short-run price dynamics back to wheat transportation costs.

In the South Caucasian countries, we found that the speed of adjustment of wheat prices with the export prices of the Black Sea wheat exporting countries was the highest in Georgia (0.34), followed by Armenia (0.32), and Azerbaijan (0.18), reflecting respective transportation cost levels.

The size of the thresholds identified in the threshold error correction model for price pairs containing Tajik wheat prices ( 0.225 , on average) were 0.05 higher than the thresholds estimated for the price pairs containing domestic wheat prices in Kyrgyzstan ( 0.175 , on average). These estimates of transaction costs for Tajikistan and Kyrgyzstan clearly correspond with the respective distance to the export markets in Kazakhstan and Russia.

The degree of market integration may also be characterized by the percentage distribution of observations in the "inner" and "outer" regimes. A higher share of observations in the "inner" regime indicates that fewer instances of market disequilibrium are observed and thus provides evidence for stronger market integration.

The distribution of the price disequilibrium term in different regimes indicates that domestic wheat prices in Central Asia are more often in an equilibrium relationship with the export price in Kazakhstan (92\%) than in Russia (89\%). This proves that domestic wheat markets in Central Asia are more strongly integrated with the export market in Kazakhstan than in Russia.

\section{Policy recommendations and discussion}

Based on the results of our analysis, we identified five points of departure for policies to improve the functioning of wheat markets and to raise food security in Central Asia and the South Caucasus (Table 8).

As our results indicate, trade costs are high in Central Asia, hindering the efficient functioning of grain markets within the region. By reducing trade costs, the wheat trade between 
Table 8 Recommended policies for improving the functioning of wheat markets in Central Asia and the South Caucasus

\begin{tabular}{|c|c|c|c|c|c|}
\hline \multirow{2}{*}{$\begin{array}{l}\text { Aims } \\
\text { Policy } \\
\text { measures }\end{array}$} & \multicolumn{4}{|l|}{ Foster wheat trade } & \multirow{2}{*}{$\begin{array}{l}\text { Increase self- } \\
\text { sufficiency } \\
\text { Boost wheat } \\
\text { production }\end{array}$} \\
\hline & $\begin{array}{l}\text { Invest in transport } \\
\text { infrastructure }\end{array}$ & $\begin{array}{l}\text { Eliminate unofficial } \\
\text { payments }\end{array}$ & $\begin{array}{l}\text { Invest in storage } \\
\text { facilities }\end{array}$ & $\begin{array}{l}\text { Resolve geopolitical } \\
\text { conflicts }\end{array}$ & \\
\hline Kyrgyzstan & $\mathrm{x}$ & $\mathrm{x}$ & $\mathrm{x}$ & & $\mathrm{x}$ \\
\hline Tajikistan & $\mathrm{x}$ & $\mathrm{x}$ & $\mathrm{x}$ & & $\mathrm{x}$ \\
\hline Uzbekistan & $\mathrm{x}$ & $\mathrm{x}$ & $\mathrm{x}$ & & $\mathrm{x}$ \\
\hline Armenia & & & & $\mathrm{x}$ & $\mathrm{x}$ \\
\hline Azerbaijan & & & & & $\mathrm{x}$ \\
\hline Georgia & & & & & \\
\hline
\end{tabular}

wheat exporting and wheat importing countries will be spurred, which contributes to stabilizing prices and strengthening market integration. Investments in transport infrastructure, public or private, are fundamental for reducing transportation costs in Central Asia. In this context, the Belt and Road Initiative project (HKTDC 2017), which aims to facilitate intra-regional trade in Central Asia, may provide a suitable platform for improving the region's transportation system.

In addition, the governments of Central Asian countries should give priority to designing and implementing effective policies for eliminating unofficial payments, which are another significant factor impacting high transportation costs in the region.

We also find that wheat price volatility is significantly higher in Central Asia than in the South Caucasus or the Black Sea region. An increase in domestic wheat storage facilities in the Central Asian countries, where wheat storage capacity is less than one week (FEWS NET 2016), would facilitate managing the wheat price risk and contribute to stabilizing wheat prices and reducing price volatility. Grain stocks could also serve as a crisis management measure. For example, strongly increasing wheat prices could be counteracted by releasing grain stocks (Schmitz and Kennedy 2016).

Our analysis has identified that in the South Caucasus, Armenia has the least diversified grain imports and the highest trade costs compared to other neighboring countries in the region. In Armenia wheat trade costs could be reduced by resolving geopolitical conflict with Azerbaijan. If Armenia and Azerbaijan would open their closed border for cargo transit at least, then Armenia could directly import wheat from Kazakhstan through Azerbaijan, substantially reducing wheat transportation costs.

However, due to large distances to grain producing regions, the grain trade could remain challenged by relatively high trade costs even in more efficient markets with modern transport infrastructure. In addition, the landlocked position of importing countries leaves little scope for diversification of wheat imports. Also, the Black Sea wheat exporters have a history of restricting wheat exports in times of crisis and the frequency of harvest shortfalls are expected to increase with climate change. Therefore, the countries in Central Asia, but also Armenia and Azerbaijan in the South Caucasus, should complement their trade enhancing policies with agricultural policies aiming to boost domestic wheat production and to increase wheat self-sufficiency. Mary (2019) conducted an empirical analysis in 52 developing countries and confirmed that increased food self-sufficiency, particularly in net food importing countries, reduced malnutrition between 1990 and 2013. Clapp (2017) discusses the instances when increases in domestic food production makes sense economically and politically to increase food security more broadly, while Watson (2017) provides the contextual analysis of food price policies chosen by the governments in developing countries from a political economy perspective. In the context of Central Asian and South Caucasian wheat markets, we advocate increased wheat self-sufficiency because of their high trade costs, landlocked geographical location, lack of diversification possibilities of grain imports (especially for Central Asia), and the high importance of food prices for the stability of political systems during periods of rising bread prices (see section 2).

Finally, Georgia is the country with the best performing wheat market in these regions by far, resulting from its market-oriented policies and favorable geographic location reflected in lower transportation costs and easy access to the grain export markets in the Black Sea region. Therefore, we see that the food insecurity prevalent in Georgia is not related to functioning of its wheat markets. Thus, to improve food security in Georgia, more consumer-oriented measures such as social safety net programs, public distribution system of food (Kumar et al. 2017) and targeted cash transfers (Chaaban et al. 2018) might play important roles.

\section{Conclusions}

In this paper we investigated wheat price relationships between the six wheat import-dependent countries in Central 
Table 9 Summary of empirical results

\begin{tabular}{|c|c|c|c|c|c|c|}
\hline & \multicolumn{3}{|l|}{ Central Asia } & \multicolumn{3}{|c|}{ South Caucasus } \\
\hline & Kyrgyzstan & Tajikistan & Uzbekistan & Armenia & Azerbaijan & Georgia \\
\hline \multicolumn{7}{|l|}{ Market integration } \\
\hline Black Sea exporters & + & + & $+/ 0$ & ++ & ++ & +++ \\
\hline World wheat markets & + & + & 0 & ++ & ++ & +++ \\
\hline \multicolumn{7}{|l|}{ Trade costs } \\
\hline Black Sea exporters & + & ++ & 0 & 0 & 0 & 0 \\
\hline World wheat markets & 0 & 0 & 0 & 0 & 0 & 0 \\
\hline Price volatility & ++ & ++ & +++ & + & + & + \\
\hline
\end{tabular}

' + ' indicates that the analysis provides positive evidence $(+=$ moderate, $++=$ moderately strong, +++ strong); ' 0 ' indicates that the analysis fails to provide positive evidence
Asia and the South Caucasus and the three Black Sea wheat exporters to assess how well these markets are functioning. Well-functioning wheat markets ensure availability and access to wheat and are crucial for reducing food insecurity, which is prevalent in countries of Central Asia and the South Caucasus.

Our results, summarized in Table 9, suggest that Georgia is the South Caucasian country with the strongest integrated wheat market, while Uzbekistan is the Central Asian country with the weakest, confirming the findings of Bluashvili and Safaryan (2014), Djuric et al. (2017), and Katsia and Mamardashvili (2016) that grain markets in the South Caucasus are well integrated. These results also confirm the findings of Bobokhonov et al. (2017), Ilyasov (2016), and Ilyasov et al. (2016) that grain markets in Central Asia are either segregated (Uzbekistan) or characterized by a lower degree of market integration with asymmetric structure of price adjustment (Kyrgyzstan and Tajikistan).

In addition, our analysis evaluated the functioning of grain markets in a comparative context, providing novel insights into the functioning of grain markets in Central Asia and the South Caucasus. From the comparative analysis it became evident that grain markets in the South Caucasus are more strongly integrated with the world wheat market compared to Central Asia. In addition, wheat price volatility is substantially higher in the wheat importing countries of Central Asia compared to the South Caucasus.

Furthermore, our modelling approach showed that trade costs significantly influence grain market integration in Central Asia, while those costs seem not to play a significant role in the integration of wheat markets in the South Caucasus. In particular, wheat trade in Central Asia is characterized not only by higher transportation costs, but unofficial payments also play a large role.

Weak integration of Central Asia's wheat markets into the world trade system, accompanied by high transportation costs and volatile wheat prices, indicates low resilience of the food system and rather high vulnerability to food insecurity.
Based on our results, we identified five policy measures for improving the functioning of wheat markets and food security in Central Asia and the South Caucasus. Kyrgyzstan, Tajikistan, and Uzbekistan should foster wheat trade by investing in transport infrastructure and storage facilities, and eliminating unofficial payments; Armenia needs to resolve geopolitical conflicts and all countries in the study region except for Georgia should increase self-sufficiency by boosting domestic wheat production.

Acknowledgments We acknowledge support by the Volkswagen Foundation through the MATRACC project 'The Global Food Crisis Impact on Wheat Markets and Trade in the Caucasus and Central Asia and the Role of Kazakhstan, Russia and Ukraine'; the Federal Ministry of Food and Agriculture (BMEL) and the Federal Office for Agriculture and Food (BLE) through the GERUKA project 'Global Food Security and the Grain Markets in Russia, Ukraine and Kazakhstan'; and the German Academic Exchange Service (DAAD). We thank Nodir Djanibekov for providing data for Uzbekistan.

\section{Compliance with ethical standards}

Conflict of interest The authors declare that they have no conflict of interest.

Open Access This article is distributed under the terms of the Creative Commons Attribution 4.0 International License (http:// creativecommons.org/licenses/by/4.0/), which permits unrestricted use, distribution, and reproduction in any medium, provided you give appropriate credit to the original author(s) and the source, provide a link to the Creative Commons license, and indicate if changes were made.

\section{References}

ADB (2006). Central Asia: Increasing Gains from Trade Through Regional Cooperation in Trade Policy, Transport, and Customs Transit. Philippines: Asian Development Bank.

Akramov, K. T. (2012). Agricultural transformation and food Security in Central Asia. In A. H. Gencer \& C. Gerni (Eds.), Central Asian economies in transition (pp. 72-89). Newcastle: Cambridge Scholars Publishing. 
Barrett, C. B. (1996). Market analysis methods: Are our enriched toolkits well suited to enlivened markets? American Journal of Agricultural Economics, 78, 825-829.

Bluashvili, A., \& Safaryan, S. (2014). Global food price shocks transmission to local markets and welfare implications for Georgian households. Policy paper conducted in the framework of the project "policy research for sustainable growth". Konrad Adenauer Foundation and $\mathrm{PMC}$ research center.

Bobojonov, I., Djanibekov, N., \& Voigt, P. (2017). Future Perspectives on Regional and International Food Security: Emerging players in the region: Uzbekistan. In P. S. G, S. Mary, \& S. Langrell (Eds.), The Eurasian Wheat Belt and food Security (pp. 195-214). Switzerland 2017: Springer International Publishing.

Bobokhonov, A., Pokrivcak, J., \& Rajcaniova, M. (2017). The impact of agricultural and trade policies on price transmission: The case of Tajikistan and Uzbekistan. The Journal of International Trade and Economic Development, 26, 677-692.

Brück, T., Esenaliev, D., Kroeger, A., Kudebayeva, A., Mirkasimov, B., \& Steiner, S. (2012). Household survey data for research on wellbeing and behavior in Central Asia. DIW Discussion Papers, No. 1257.

Chaaban, J., Ghattas, H., Irani, A., \& Alban, T. (2018). Targeting mechanisms for cash transfers using regional aggregates. Food Security, 10(2), 457-472.

Chabot, P., \& Dorosh, P. A. (2007). Wheat markets, food aid and food security in Afghanistan. Food Policy, 32, 334-353.

Chabot, P., \& Tondel, F. (2011). A regional view of wheat markets and food Security in Central Asia. United States Agency for International Development: Famine early warning systems network (FEWS NET), world food Programme.

Clapp, J. (2017). Food self-sufficiency: Making sense of it, and when it makes sense. Food Policy, 66, 88-96.

Dickey, D. A., \& Fuller, W. A. (1981). Likelihood ratio statistics for autoregressive time series with a unit root. Econometrica, 49(4), 1057-1072.

Dillon, B., \& Dambro, C. (2017). How competitive are crop markets in sub-Saharan Africa? American Journal of Agricultural Economics, 99(5), 1344-1361.

Dithmer, J., \& Abdulai, A. (2017). Does trade openness contribute to food security? A dynamic panel analysis. Food Policy, 69, 218-230.

Djuric, I., Götz, L., Svanidze, M., \& Glauben, T. (2017). Agricultural market integration in the commonwealth of independent states What are the main driving forces and challenges? In G. Egilmez (Ed.), Agricultural Value Chain (pp. 139-160). InTechOpen.

Engle, R. F., \& Granger, C. W. (1987). Co-integration and error correction: Representation, estimation and testing. Econometrica, 55, 251276.

Fackler, N. E., \& Goodwin, B. K. (2001). Spatial market integration in the presence of threshold effects. American Journal of Agricultural Economics, 83(2), 302-317.

FAO. (2009). World summit on food Security: Draft declaration of the world summit on food security. Rome: FAO.

FAO (2015a). Food and agriculture Organization of the United Nations. Retrieved from http://www.fao.org/faostat/en/\#home

FAO. (2015b). Regional overview of food insecurity: Europe and Central Asia. Rome: FAO.

FAO/EBRD. (2009). Agribusiness handbook: Wheat flour. Rome: FAO.

Fellmann, T., Hélaine, S., \& Nekhay, O. (2014). Harvest failures, temporary export restrictions and global food security: The example of limited grain exports from Russia, Ukraine and Kazakhstan. Food Security, 6(5), 727-742.

FEWS NET. (2016). Regional wheat market fundamentals. Central Asia. FEWS NET.

Fiamohe, R., Seck, P. A., \& Alia, D. Y. (2013). Price transmission analysis using threshold models: An application to local rice markets in Benin and Mali. Food Security, 5(3), 427-438.
Goodwin, B. K., \& Piggott, N. E. (2001). Spatial market integration in the presence of threshold effects. American Journal of Agricultural Economics, 83(2), 302-317.

Götz, L., Djuric, I., \& Nivievskyi, O. (2016). Regional price effects of extreme weather events and wheat export controls in Russia and Ukraine. Journal of Agricultural Economics, 67(3), 741-763.

Götz, L., Glauben, T., \& Brümmer, B. (2013). Wheat export restrictions and domestic market effects in Russia and Ukraine during the food crisis. Food Policy, 38, 214-226.

Granger, C., \& Newbold, P. (1974). Spurious regressions in econometrics. Journal of Econometrics, 2(2), 111-120.

Greb, F., von Cramon-Taubadel, S., Krivobokova, T., \& Munk, A. (2013). The estimation of threshold models in price transmission analysis. American Journal of Agricultural Economics, 95(4), 900-916.

Hansen, B. E., \& Seo, B. (2002). Testing for two-regime threshold cointegration in vector error-correction models. Journal of Econometrics, 110, 293-318.

HKTDC (2017). Hong Kong trade development council: Belt and road initiative. Retrieved from www.beltandroad.hktdc.com

Ilyasov, J. (2016). Fuel to food: Evidence of price pass-through in Kyrgyzstan. Research paper presented at the Samarkand Conference "Regional and International Cooperation in Central Asia and South Caucasus: Recent developments in Agricultural Trade", November 2-4, 2016. Samarkand, Uzbekistan.

Ilyasov, J., Götz, L., Akramov, K., Dorosh, P., \& Glauben, T. (2016). Market integration and Price transmission in Tajikistan's wheat markets: Rising like rockets but falling like feathers? IFPRI discussion papers \#01547.

International Seaborne Market. (2015). Retrieved from www.me-freight. com.

Jamora, N., \& von Cramon-Taubadel, S. (2016). Transaction cost thresholds in the international rice markets. Journal of Agricultural Economics, 67(2), 292-307.

Johansen, S. (1988). Statistical analysis of cointegration vectors. Journal of Economic Dynamics and Control, 12(2-3), 231-254.

Katsia, I., \& Mamardashvili, P. (2016). Price transmission on wheat flour market in Georgia. Contributed Paper presented at the InterConference Symposium of IAAE "Agricultural Transition along the Silk Road", 4-6 April, Almaty, Kazakhstan.

Kumar, A., Parappurathu, S., Babu, S. C., \& Joshi, P. K. (2017). Can better governance improve food security? An assessment of the public food distribution system in Odisha, India. Food Security, 9(6), 1433-1445.

Lo, M. C., \& Zivot, E. (2001). Threshold cointegration and nonlinear adjustment to the law of one price. Macroeconomic Dynamics, 5(4), 533-576.

MacKinnon, J. G. (1996). Numerical distribution functions for unit root and cointegration tests. Journal of Applied Econometrics, 11, 601618.

Mary, S. (2019). Hungry for free trade? Food trade and extreme hunger in developing countries. Food Security. https://doi.org/10.1007/ s12571-019-00908-z.

Matz, J. A., Kalkuhl, M., \& Abegaz, G. A. (2015). The short-term impact of price shocks on food security-evidence from urban and rural Ethiopia. Food Security, 7(3), 657-679.

Mori Clement, Y., Bhaduri, A., \& Djanibekov, N. (2014). Food price fluctuations in Uzbekistan: Evidence from local markets in 20022010. In J. P. Lamers, A. Khamzina, I. Rudenko, \& P. L. Vlek, Restructuring land allocation, water use and agricultural value chains: technologies, policies and practices for the Lower Amudarya Region (pp. 275-294). Gottingen, Germany: V\&R unipress, Bonn University Press.

Moser, C., Barrett, C., \& Minten, B. (2009). Spatial integration at multiple scales: Rice markets in Madagascar. Agricultural Economics, 40(3), 281-294. 
Ortiz, I., Burke, S., Berrada, M., \& Cortes, H. (2013). World protests 2006-2013. Initiative for Policy Dialogue \& Friedrich-EbertStiftung.

Perron, P., \& Vogelsang, T. J. (1992). Nonstationarity and level shifts with an application to purchasing power parity. Journal of Business and Economic Statistics, 10, 301-320.

Pinheiro, J., Bates, D., DebRoy, S., Sarkar, D., \& R Core Team. (2017). nlme: Linear and Nonlinear Mixed Effects Models. R package version 3.1-131. www.CRAN.R-project.org/package=nlme.

Pomfret, R. (2016). Improved Infrastructure and Central Asian Exports of Agricultural Commodities. Presented at the conference "Regional and International Cooperation in Central Asia and South Caucasus: Recent Developments in Agricultural Trade", November 2-5, Samarkand, Uzbekistan.

Pugach, I., Yusupov, Y., \& Berdinazarov, Z. (2016). Agricultural policy in wheat production and crop diversification in Uzbekistan. IAMO Discussion Paper No. 157, Halle (Saale): IAMO.

RFE/RL. (2008). Tajikistan: UN urges food aid, as anger mounts over energy crisis. Retrieved from www.rferl.org/a/1079499.html.

Robinson, W. I. (2008). Regional market survey for the Caucasus sub region. Report of Mission, World Food Programme.

Schmitz, A., \& Kennedy, L. (2016). Food Security and the role of food storage. In A. Schmitz, L. Kennedy, \& T. G. Schmitz (Eds.), Food Security in a food abundant world (pp. 1-17) Emerald Group Publishing Limited.

Schroeder, K. G., \& Meyers, W. H. (2016). The status and challenges of food Security in Europe and Central Asia. In A. Schmitz, P. L. Kennedy, \& T. G. Schmitz (Eds.), Food Security in a food abundant world (Vol. 16, pp. 85-103) Emerald Group Publishing Limited.

Sutton, W. R., Srivastava, J. P., \& Neumann, J. E. (2013). Looking beyond the horizon: How climate change impacts and adaptation responses will reshape agriculture in Eastern Europe and Central Asia. Washington, DC: World Bank.

Svanidze, M., \& Götz, L. (2019). Spatial market efficiency of grain markets in Russia and global food security: A comparison with the USA. IAMO Discussion Paper No. 187, Halle (Saale): IAMO.

Swinnen, J., \& van Herck, K. (2011). Food Security and the transition region. Rome: FAO investment Centre division.

Swinnen, J., \& Van Herck, K. (2013). Food Security and Sociopolitical Stability in Eastern Europe and Central Asia. In C. B. Barrett, F. Security, \& S. Stability (Eds.), Food Security and sociopolitical Stability in Eastern Europe and Central Asia (pp. 381-405). Oxford: Oxford University Press.

Takayama, T., \& Judge, G. G. (1971). Spatial and temporal Price and allocation models. Amsterdam: North-Holland Publishing Company.

TRACECA (2017). Transport Corridor Europe-Caucasus-Asia. Retrieved from www.traceca-org.org/en/routes/maps-downloadsgis-database/

Ubilava, D. (2017). The ENSO effect and asymmetries in wheat price dynamics. World Development, 96, 490-502.

UN Comtrade (2016). Online database. Retrieved from http://comtrade. un.org/.

USDA-ERS (2016). United States Department of Agriculture: Economic research service. Retrieved from https://www.ers.usda.gov/

USDA-FAS (2016). Foreign Agricultural Service - United States Department of Agriculture. Retrieved from https://www.fas.usda. gov/

Van Campenhout, B. (2007). Modelling trends in food market integration: Method and an application to Tanzanian maize markets. Food Policy, 32, 112-127.
Veninga, W., \& Ihle, R. (2018). Import vulnerability in the Middle East: Effects of the Arab spring on Egyptian wheat trade. Food Security, 10(1), 183-194.

Watson, D. (2017). The political economy of food price policy during the global food price crisis of 2006-2008. Food Security, 9(3), 497-509.

WFP (2016). World Food Programme. Retrieved from http://www.wfp. org/

WHO (2016). World Health Organization. Retrieved from http://www. who.int/en/

World Bank (2005). Tajikistan trade diagnostic study. World Bank report.

World Bank (2011). Central Asia: Expanding trade by connecting with markets. Report No. 53556-ECA.

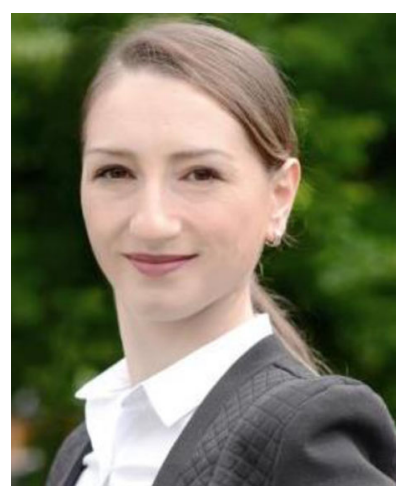

Miranda Svanidze has beeen a doctoral candidate at the Leibniz Institute of Agricultural Development in Transition Economies (IAMO) since 2014. She received a doctoral grant from the German Academic Exchange Service (DAAD) to conduct research on the functioning of wheat markets in importdependent countries of Central Asia and the South Caucasus and grain exporting countries in the Black Sea region. Her research interest is focused on price transmission analysis, market integration, regional trade and inefficiencies in agricultural markets.

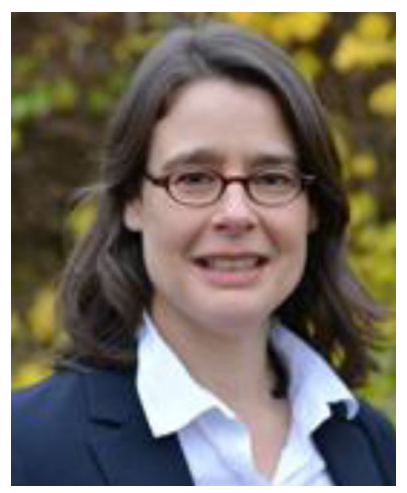

PD Dr. habil. Linde Götz has been Deputy Head of the Department of Agricultural Markets at the Leibniz Institute of Agricultural Development in Transition Economies (IAMO) since 2013. She graduated with a Master's degree in Agricultural Economics from Humboldt University, Berlin, was awarded an MSc in Applied Economics from the University of Minnesota (USA) and obtained her $\mathrm{PhD}$ from the University of Gottingen. Central to her research interest is the analysis of competition and efficiency of agricultural markets and supply chains and the effectiveness of agricultural policies based on time-series econometric analysis of price transmission and price volatility in the countries of the post-Soviet states. A further emphasis lies on the development of the agricultural and food industry of Russia and its implications for global food security and the food sector of Germany. 


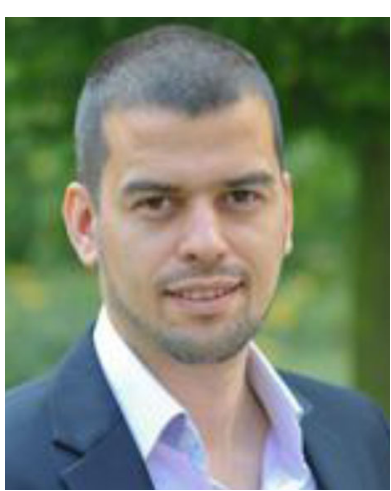

Dr. Ivan Duric joined the Leibniz Institute of Agricultural Development in Transition Economies (IAMO) in October 2008 as a junior researcher in the Department Agricultural Markets. He wrote his $\mathrm{PhD}$ thesis about the impact of policy measures on the wheat-to-bread supply chain during the global commodity price peaks (the case of Serbia). For his $\mathrm{PhD}$ research he was honoured with the highest grade (summa cum laude) by the Martin Luther University HalleWittenberg, Faculty of Agriculture, Germany. Duric continues his research at IAMO on the topics of price transmission, market integration, agricultural trade policy, and world agricultural trade.

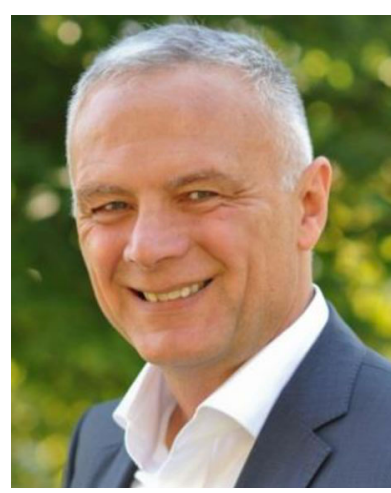

Prof. Dr. Thomas Glauben is a Director of the Leibniz Institute of Agricultural Development in Transition Economies (IAMO) and Head of the Department Agricultural Markets. He is also a full professor at the Faculty of Natural Science III and a co-opted professor at the Law and Economics Faculty of the Martin Luther University HalleWittenberg, Germany. From 2013 to 2015 he was a member of the Presidium of the Leibniz Association. Currently, he is a member of the boards of various journals and trade publishers. Since 2007 he has been an associate member of the REAP Center of Stanford University, USA. Prof. Dr. Thomas Glauben studied agricultural science at Kiel University, where he obtained his doctorate and habilitated. 